\title{
APPLICABILITY OF THE FEDERAL SECURITIES LAWS TO PENSION AND PROFIT-SHARING PLANS*
}

\author{
Robert H. Mundheim $\dagger$ and Gordon D. Henderson $\ddagger$
}

On December 7, 1962 the Chase Manhattan Bank published in the New York Times what it termed "An Important Announcement from the Chase Manhattan Bank to All People Who Are Self-Employed." 'The announcement stated that self-employed persons could for the first time take part in "tax-approved pension or profit-sharing plans." Then under a caption entitled "WHAT WE'LL Do," the Chase Manhattan Bank stated that it expected to establish two trust funds-a fixed-income trust fund and an equity fund-"For investment purposes of self-employed retirement plans." The announcement went on to state that the person setting up the self-employed retirement plan had the right at the time each contribution was made to select either or both funds as the investment medium for such contribution.

The announcement elicited an almost immediate response from the Chief Counsel of the Division of Corporation Finance of the Securities and Exchange Commission ${ }^{3}$ who warned that the Chase Manhattan Bank had made a public offering of a security without complying with the registration requirements of the Securities Act of 1933. ${ }^{4}$ This warning was greeted by some people in banking circles with an appearance of surprise. It also provoked a stormy reaction from the Comptrolle of the Currency who stated that his investigations had led to "far different conclusions of law" than those announced by the Chief Counsel of the Division of Corporation Finance..$^{5}$ Although the banking fraternity had not been unaware

- This article bears a date of June 5,1964 .

†A.B. 1954, LL.B. I957, Harvard University. Visiting Professor of Law, Duke University. Consultant, Securities and Exchange Commission. Member of the New York bar.

¥A.B. 195I, LL.B. 1957, Harvard University. Special Counsel to Securities and Exchange Commission on Investment Company Act Matters and Associate Director of its Division of Corporate Regulation. Member of the District of Columbia bar.

The Securities and Exchange Commission, as a matter of policy, disclaims responsibility for any private publication by any of its employees. The views expressed herein are those of the authors and do not necessarily reflect the views of the Commission or of the authors' colleagues on the staff of the Commission.

${ }^{2}$ N.Y. Times, Dec. 7, I962, p. 29, cols. 2-7.

3 The announcement refers to the Self-Employed Individuals Tax Retirement Act of I962, 76 Stat. 809 (1962).

a The response came at a session of the Practising Law Institute in New York City, held on Dec. 7, 1962, which was devoted to a discussion of pension and profit-sharing plans for the self-cmployed.

${ }_{48}$ Stat. 74 (1933), as amended, I5 U.S.C. $\$ 77 \mathrm{a}-\mathrm{aa}$ (1958), as amended, 15 U.S.C. $\$ 77 \mathrm{~b}-77^{\mathrm{h}}$ (Supp. IV, 1963 ) [hereinafter cited as Securities Act].

- Letter from James J. Saxon, Comptroller of the Currency, to William L. Cary, Chairman, Securities and Exchange Commission, Dec. 18, 1962, in Common Trust Funds-Overlapping Responsibility and Conflict in Regulation, Hearing Before a Subcommittee of the House Committee on Government Operations, 88th Cong., Ist Sess. 134 (1963) [hereinafter cited as Fascell Hearing].

Interestingly, in the course of the Fascell Hearing, which investigated the relationship of the federal securities laws to certain aspects of the Comptroller of the Cursency's Regulation 9, 12 C.F.R. pt. 9, 
that their offering of interests in commingled funds as the investment media for retirement plans raised questions under the federal securities laws, ${ }^{0}$ these reactions are to some extent understandable in light of the Commission's traditional reluctance to take action to apply the federal securities laws to pension plans in any but a narrow category of cases or to bank commingled funds in which only the assets of pension plans were invested.

The basis for the Commission's reluctance to act in the retirement plan area has never been clearly articulated; nor has the appropriateness of applying the federal securities laws to some or to all of the many forms of such plans been thoroughly analyzed. This neglect is surprising in light of the increasingly important role which pension plans play in the American economy. The development of pension plans, as a supplement to the social security system, represents a major effort in the American economy to find a satisfactory answer to the need for providing a degree of economic security for those who have reached retirement age. Growth in the size of pension plans has been phenomenal. Ten years ago, the book value of private non-insured pension funds was $\$$ Ir billion; today it is over $\$ 46$ billion. Net receipts totalled $\$ 2$ billion a year in the mid-r950s and $\$ 4$ billion annually in 1962-63: It has been estimated that they will amount to $\$ 6$ billion annually by 1970 and $\$ 8$ billion annually by $1980 .^{7}$

later amended by 29 Fed. Reg. I7I9 (I964) [hereinafter cited as Regulation 9], Mr. Saxon testified that the advertisement of the Chase Manhattan Bank "would be proscribed under our regulation." But see note 116 , infra.

He pointed out that "there can be no question of any mass merchandising under our regulation." Fascell Hearing 48. In a letter "To All National Banks and State Banks Operating Common' Trust Funds," dated April 5, 1963, which accompanied the revision of Regulation 9, Mr. Saxon stated that a bank which published "an advertisement which made other than incidental mention of its common trust fund in the course of advertising the range of the bank's fiduciary services, would violate this Regulation." The advertisement of The First National City Bank of New York with respect to self-employed retirement plans which was published in the New York Times on Tuesday, Dec. 3, 1963, appears to be an example of the kind of advertisement which Regulation 9 contemplates. As of June 5, I964, the Securities and Exchange Commission had taken no action against The First National City Bank of New York for publishing this advertisement.

'In 5960 , in connection with an earlier version of the Self-Employed Individual's Tax Retirement Act of 1962 , the American Bankers Association formally requested the Commission to join with it in proposing an amendment to the bill which would exempt interests in self-employed persons' retirement plans either from all of the provisions of the Securities Act and Investment Company Act of 1940, 54 Stat. 789 , 15 U.S.C. $\$ \$ 80 a-2$ to -39 (Supp. IV, 1963) [hereinafter cited as Investment Company Act], or from all of these provisions except the anti-fraud provisions of the Sccurities Act. The Commission declined to do so and the language was not presented by the Association to the Congress. No similar discussions were held or similar language proposed in connection with the Self-Employed Individual's Tax Retirement Act of 1962 itself.

"Fortune, Feb. 1964, p. 198. SEC Statistical Series Release No. 1978, June 4, 1964. The market value of these funds is slightly higher than $\$ 54$ billion. Ibid. In addition to the assets of these private non-insured pension plans, there are today about $\$ 23$ billion in insured pension assets. Forbes, April I, 1964, p. 37 . In contrast, it is interesting to note that the assets of the principal social security fund, the Old Age and Survivor's Insurance Trust fund, amounted to only $\$ 18.5$ billion at the end of $\mathrm{I}_{963}$, while the assets of the retirement systems of the state and local governments amounted to $\$ 27$ billion. SEC Statistical Series Release No. 1978, June 4, 1964. See PAur. P. Harbrecht, Pension Funds AND Economic Power 237-50 (1959), for a discussion of the potential growth of pension funds and the channelling of their investments. This excellent book discusses the impact of private noninsured pension plans upon the ownership and control of productive property in the United States. 
This article will analyze pension and profit-sharing plans by attempting to identify the interests they contain and the extent to which the federal securities laws should appropriately be used to protect those interests. ${ }^{8}$ In making this analysis, self-employed retirement plans will be used as a primary frame of reference. The principal conclusions which are reached can be summarized as follows. The general reluctance of the Commission to apply the Securities Act to pension and other employee benefit plans that do not involve the sale to employees of securities in the employer company appears appropriate. Different considerations, however, are involved in connection with offerings of commingled investment funds, such as those described in the advertisement of the Chase Manhattan Bank mentioned at the beginning of this article, to large numbers of relatively unsophisticated employers as possible investment media for their H.R. Io plans. The registration and disclosure provisions of the Securities Act should in general be applied to such offerings. The provisions of the Investment Company Act have not been applied to qualified pension plans (including H.R. ro plans) at either the employer or the commingled fund level. Although this seems appropriate at the level of the individual employer plan, at the level of the commingled fund the similarity of the H.R. Io commingled fund to the typical investment company creates difficulties of articulating adequate policy reasons for the distinctions drawn in the act between funds which are exempt and funds which are not.

\section{I}

The H.R. io Plan

H.R. Io, the popular name for the Self-Employed Individuals Tax Retirement Act of 1962 , provides a vehicle by which self-employed persons are granted some of the favorable tax benefits which are available in connection with qualified pension plans established by employers for their employees. ${ }^{9}$ ('The latter type pension plan

It points out many of the important questions which the growth of these plans raises. See Securities and Exchange Commission, Report of Special Study of Securities Markets, H.R. Doc. No. 95, pt. 2, 88th Cong., rst Sess. 837-70 ( 1963 ), for a description and analysis of the way pension funds and other institutional investors execute stock transactions and utilize the securities markets.

"This article will not discuss the extent to which the "blue sky" laws or other state legislation protect the interests of pension plan participants. Most state blue sky laws either specifically exempt from their operation "investment contracts" or "securities" issued in coninection with an employee's stock purchase, savings, pension, profit-sharing or similar benefit plan, see, e.g., N.Y. GEN. Bus. Lnw $\$ 359$-f-2.(e) (Supp. I963), or grant an exemption if the state securities commissioner is given notice of the plan a specified period before its inception. See, e.g., N.J. Rev. Star. $\$ 49: 3-3$ (a) (5) (Supp. I963). For a summary of the treatment given to pension plans under state blue sky laws, see P-H PENsion \& Profit-Shuring Rep. I 6231 ( $1963-64)$.

"Partners and individual proprietors (neither of which are considered "employees" under the Internal Revenue Code, except under the special provisions of H.R. Io) have always been able to set up qualified pension funds for their employees; but the only way they can cover themselves under a qualified plan is by setting up an H.R. ro plan. The tax advantages of traditional employee qualified pension plans remain much greater than those extended to H.R. ro plans. This point was articulated in the following manner in the minority views appended to the Senate Finance Committee's report on H.R. Io:

"The bill fails even to accomplish its major ostensible objective of equating retirement privileges of the self-employed with those of the executive of closely held corporations. To achieve parity in this regard, limitations of considerable stringency would need to be placed on corporate executives. The 
will sometimes be referred to in this article as an employee pension plan in order to distinguish it from the self-employed person's pension plan which will usually be referred to as an H.R. ro plan.) The tax advantages to a self-employed person in establishing an H.R. xo plan are two-fold: A deduction can be taken for at least a part of his contribution to the plan; and the income earned on his contributions after they have been invested under the plan is tax exempt until distributed to him.

The amount which a self-employed person can contribute for himself in any one year under such a plan is in general limited to the lesser of ten per cent of his earned income for such taxable year derived from the trade or business with respect to which the plan is established, or $\$ 2,500 .^{10}$ Only fifty per cent of the amount so contributed by the self-employed individual for himself is deductible. ${ }^{11}$ As a condition of establishing an H.R. ro plan, the self-employed person must include under the plan all his employees (except part-time and seasonal employees) who have three or more years' service in the trade or business with respect to which the plan is established; and he must make contributions on their behalf on a basis at least as favorable as the basis on which the contributions on his own behalf are made. ${ }^{12}$ Such employees may be permitted by the plan to make voluntary contributions. These are not deductible by the employees but the earnings on them are tax exempt until distributed. ${ }^{13}$ All contributions made with respect to employees are required by H.R. Io to vest in the employees immediately (i.e., they must be nonforfeitable). ${ }^{14}$

Contributions made pursuant to H.R. ro plans may be funded in any one or more of the following ways:

(I) By deposit of the funds in a trust of which a bank is the trustee. The statute

committee refused to acknowledge this fact and summarily voted down all attempts in that direction." S. REP. No. 992, 87th Cong., Ist Sess. 56 (1961).

${ }^{10}$ INT. REv. CODE of I954, $\$ 404(\mathrm{e})(\mathrm{I})$. For the special treatment applicable to self-employed persons who are not "owner-employees," see note ir infra.

${ }^{11}$ INT. Rev. CODE of 1954, \$404(a)(10). The Code classifies self-employed persons into two groups: The first group consists of persons who are defined in $\$ 4 \operatorname{or}(c)(3)$ as "owner-employces." These are persons who are sole proprietors and partners who own more than a $10 \%$ capital or profits interest in a partnership. The rules described in the text are those which apply to owner-employecs. For self-employed persons who are not owner-employees (i.e., partners who do not have a greater-than$10 \%$ capital or profits interest in the partnership) a somewhat more liberal rule applies. Their contributions to the plan on their own behalf are not limited by the lesser of $10 \%$-of-earned-income or $\$ 2,500$ test mentioned above. But the deduction they may take for their own contributions is limited to $50 \%$ of that portion of their contribution which does not exceed the lesser of $10 \%$ of their carned income from the partnership or $\$ 2,500$.

${ }^{12}$ INT. REV. CODE OF 1954, $\$ 40 I$ (d) (3). The contributions made by the self-employed person on behalf of his employees are deductible in full by him, and are not currently taxed to the cmployecs.

${ }^{13}$ Voluntary contributions made by an employee generally should not be permitted to exceed $10 \%$ of his compensation for the taxable year. See Rev. Rul. 59-185, 1959-r CuM. Bunz. 86.

If the plan permits voluntary contributions to be made by employees, the self-employed person is also permitted to make voluntary contributions on a comparable basis. No part of these voluntary contributions is deductible. Voluntary contributions made by an owner-employee are limited to the lesser of $10 \%$ of his earried income from the trade or business or $\$ 2,500$. INT. REv. CoDE of 1954, $\$ 401$ (C)(I)(B) (ii), (iii).

is INT. REv. CODE OF I954, \& 401 (d)(2)(A). 
does not place any limitation on the investments which the trust may make. And it permits persons (including the employer) other than the bank to have the power to determine what these investments will be. One of the possible investment media for the trust is a bank commingled fund. Other possible investment media would include shares in mutual funds or closed-end investment companies, or face-amount certificates issued by registered investment companies. The trustee is required to file information returns regarding the trust with the Treasury. If the trust uses annuity, endowment, or life insurance contracts of a life insurance company exclusively as its funding medium, the trustee need not be a bank if the life insurance company files certain information returns regarding the contracts with the Treasury.

(2) By investment of the funds directly in nontransferable annuity contracts. The term "annuity" includes variable annuities, and face-amount certificates issued by registered investment companies. The company issuing the contracts is required to file information returns regarding the contracts with the Treasury.

(3) By establishment of a special custodial account with a bank, if the funds in the account are invested solely in shares of regulated investment companies, as defined in section $85 \mathrm{I}$ of the Internal Revenue Code of 1954, which issue only redeemable shares, or solely in annuity, endowment or life insurance contracts. The term "annuity" includes variable annuities, and face-amount certificates issued by a registered investment company. The custodian is required to file information returns regarding the account with the Treasury.

(4) By investment of the funds in a special series of United States bonds, registered in the name of the employee. These bonds may be held directly since they are nontransferable and can only be redeemed under specified circumstances.

In general, each individual H.R. Io plan will be small. The number of participants in the plan and the assets contributed in their behalf will be relatively limited (this will be particularly true in the early years of the plan). As a consequence, it will not be practical to provide adequate diversification or management for the investment of the assets in such plans unless the assets of a large number of such plans can be commingled. Banks which offer H.R. Io programs do so on the assumption that a substantial number of such plans will be established with them, and, as the Chase Manhattan advertisement mentioned at the beginning of this article indicates, that the assets of these plans will be invested in their commingled funds. One bank predicted that it would have $\mathrm{I} 8,000 \mathrm{H}$.R. Io participants within one year after commencing its H.R. Io program. Failure to obtain a large number of H.R. to plans and to commingle their assets for the purposes of investment management would result in banks having to charge higher fees or operating their H.R. Io programs at a loss. ${ }^{15}$

${ }^{23}$ So far the high hopes for the widespread use of H.R. ro plans do not appear to have been realized. The principal reason seems to be that from the self-employed individual's point of view participation in an H.R. Io plan may create costs that could well outweigh any immediate tax saving which is secured. See Hoffmann, Many Limitations of H.R. Io Make Its Use Generally Undesirable, I8 J. TAXATIoN 218 (1963). 
Although H.R. ro plans may take the form of pension plans under which definitely determinable benefits are paid out and to which actuarially determined contributions are made, it seems more likely that such plans will be profit-sharing plans (so that contributions will be required only in profitable years) and that pay outs under the plans will vary with the success of the investment of the assets contributed to the plans. The plans which have been registered with the Securities and Exchange Commission contemplate that a substantial part of the contributions to the plan will be invested in securities. ${ }^{16}$

One way of setting up an H.R. ro plan-and the one with which we will be most concerned for the purposes of analysis-is for the employer to create a trust, of which a bank will be the trustee, to which the contributions on behalf of the employer and his employees under the plan will be made. The trust agreement will describe the investment powers of the trustee. The trustee may be directed to invest the funds contributed to the trust in one or more of the bank's commingled funds, or partly in one or more commingled funds and partly in some form of insurance, or the trustee may be given complete discretion with respect to the investment of the trust assets; or the trustee may be told what percentage of the trust assets it shall invest in commingled funds and what percentage in insurance, but be given discretion with respect to the commingled fund or funds in which it will invest. As indicated above, it is also possible for the trust instrument to provide that some person other than the trustee-such as the employer or the participants through the employer-will have the power to determine what the investments will be. For example, the employer might retain the power to determine what portion of the contributions in any year will be invested in the bank's commingled stock fund, or its commingled balanced fund, or in annuity contracts or investment company shares. The employer could also retain the power to switch existing investments.

Typically, the documents which will be used to set up the plan and the trust created pursuant to it will be supplied by the sponsor of the H.R. Io program. For example, the American Bar Retirement Association, which sponsors an H.R. Io program for members of the American Bar Association, indicates that a copy of the retirement plan, the implementing trust agreements, instructional materials and other forms needed to adopt the plan can be purchased for $\$ 5.00$. The First National City Bank of New York advertises the availability of Master Pension Plans and Master Profit Sharing Plans and a Trust Agreement form for use with each of these plans. It appears that these plans and the trust agreements must be standardized in order to achieve the necessary volume operating economies. ${ }^{17}$

\footnotetext{
${ }^{10}$ See, e.g., American Bar Retirement Association Retirement Plan.

${ }^{17}$ See Announcement From the American Bar Association to Its Members, Nov. 19, 1963.
} 
II

\section{Is There a Security?}

The federal securities laws are designed to protect investor interests. Thus, in determining the applicability of the federal securities laws to a particular situation, identification of an investor interest is required. Traditionally, the presence of such an investor interest is premised in Securities Act terms on the existence of a "sale" of a "security." The applicability of the concept of a "sale" in the pension plan context will be examined in the next section. Here we shall examine the question whether a "security" exists.

A "security" is defined in section 2(I) of the Securities Act to mean:

... any note, stock, treasury stock, bond, debenture, evidence of indebtedness, certificate of interest or participation in any profit-sharing agreement, collateral-trust certificate, pre-organization certificate or subscription, transferable share, investment contract, voting-trust certificate . . . or, in general, any interest or instrument commonly known as a "security"....

The House report on the Securities Act indicates that the term security is broadly defined so that "the many types of instruments that in our commercial world fall within the ordinary concept of a security" will be subject to the disclosure requirements of the Securities Act. ${ }^{18}$ The decisions of the courts construing the term security have been characterized as liberal and as bringing within the act "many forms of transactions which, on their face, do not appear to be 'securities' in the commercial sense of the word."19

The Commission has concentrated its attention in the pension plan area under the Securities Act almost exclusively on plans funded by a trust which invests in securities, mortgages, or similar investments. This concentration appears related to that fact that such trusteed plans have the characteristics of investment companies. ${ }^{20}$ In analyzing the status under the Securities Act of trusteed pension plans which invest in or hold securities or mortgages or similar investments, the Commission has traditionally taken the position that interests in such pension plans constitute "investment contracts" or "certificates of interest or participations in a profit-sharing

${ }^{18}$ H.R. Rep. No. 85, 73d Cong., Ist Sess. II (1933).

${ }^{18}$ Feldman \& Rothschild, Executive Compensation and Federal Securities Legislation, 55 Mrch. L. REv. III5, III7 (I957).

${ }^{20}$ As Commissioner Purcell testified before the House Committee on Interstate and Foreign Commerce in 1941: "Many employee plans are in the nature of investment trusts and are indistinguishable in legal effect from investment companies offering securities to the public at large. The Congress in the Investment Company Act of 1940 recognized this fact by providing certain limited exceptions from the provisions of that act for 'employees' securities companies' in sections 3 (c)(13) and $6(\mathrm{~b})$. " Hearings on Proposed Amendments to the Securities Act of 1933 and to the Securities Exchange Act of 1934 Before the House Committee on Interstate and Foreign Commerce, 77th Cong., Ist Sess. 895 (r94I) [hereinafter cited as the $194 \mathrm{I}$ Hearings]. Indeed, it appears that the Commission did not attempt to apply the Securities Act to trusteed pension plans generally until about the time that the Investment Company Act was being drafted. See $i d$. at 958-62, 975, 994. Before that time the Commission seems to have limited the applicability of the Securities Act to plans which provided for the purchase of stock by employees in the employer company. 
agreement."21 An investment contract has been defined by the U.S. Supreme Court in Securities and Exchange Commission v. Howey to mean:

... a contract, transaction or scheme whereby a person invests his money in a common enterprise and is led to expect profits solely from the efforts of the promoter or a third party, it being immaterial whether the shares in the enterprise are evidenced by formal certificates or by nominal interests in the physical assets employed in the enterprise. ${ }^{22}$

When the Supreme Court's definition of investment contract is applied to the trusteed pension plan with which we are primarily concerned-the H.R. ro trustthe existence of a security is clearly indicated. Money is invested in a common enterprise (the trust which receives the contributions of the employer and his employees), the management of which is committed to a third party (the trustee and, in some cases, the employer or some other person) and from which profits (and income) are expected. However, when the investment contract test is applied to the bank commingled fund which may be used to pool the assets of various employercreated H.R. ro trusts, the result is less easily apparent. Since the trustee of each employer-created trust is also the trustee of the commingled fund, if the trustee is viewed as the "person" making the investment in the commingled fund there does not seem to be, in substance, a third party to whom the management of the common enterprise is entrusted. But to the extent that the trustee of the employer-created trust is directed to invest in 2 particular commingled fund or to the extent that he is given discretion to invest in a particular commingled fund and there is an understanding that he will do so or he uniformly exercises his discretion to do so, it is really the employer who, in substance, makes the investment in the commingled fund. In any event, there is no difficulty in viewing each employer-created trust as having a "certificate of interest or participation in a profit-sharing agreement" as a consequence of the arrangement by which each trust shares, pro rata in relation to its contributions, in the success of the commingled fund. ${ }^{23}$

Where the issuer of the security is a trust, the identification of a security is only

${ }^{21}$ Op. SEC Ass't Gen. Counsel (194I), I CCH Fed. SEc. L. REp. \2231.21. Perhaps because of its concentration on the investment company nature of trusteed plans, Commission statements concerning them do not distinguish between the plan and the trust which is used to fund it.

22328 U.S. $293,298-99$ (1946).

23 One of the important changes which Regulation 9 effected in the rules governing commingled funds is that in determining the placement of a particular participation in a fund, the entire fund as a whole rather than each asset in the fund may be considered in determining the propriety of the particular participation. Thus, even if one of the investments of the commingled fund would not qualify as a proper investment for the participating account, the commingled fund may still be considered a proper investment medium for the account. This reflects the adoption of an entity theory with respect to the commingled fund. See Remarks of James J. Saxon, Comptroller of the Currency, 44th Midwinter Trust Conference of the American Bankers Association, Feb. 4, I963; Letter To All National Banks and State Banks Operating Common Trust Funds, April 5, 1963, supra note 5.

The Internal Revenue Service has traditionally treated bank commingled funds set up as investment media for qualified plans as separate entities. See Rev. Rul. 56-267, x956-I Cum. Busz. 206. In Rev. Rul. 57-165, 1957-1 Cum. BuLz. I67, the Service held that a transfer of property from the employer's individual trust to the commingled fund constitutes an exchange resulting in the realization of gain or loss by the individual trust. Similar treatment has been applied for tax purposes to traditional common trust funds. See INT. Rev. Code of 1954, $\$ 58_{4}$ (c); U.S. Treas. Reg. $\$ 1.584-4$ (b). 
a short first step in identifying an investor interest. The broad scope of the terms "investment contract" or "certificate of interest or participation in any profit-sharing agreement" results in the issuance of a security almost every time a trust is created. To preclude such a result, a person who issues a security was defined in section 2(2) of the Securities Act to exclude all trusts unless "the interest or interests of the beneficiary or beneficiaries are evidenced by a security" (emphasis added). The "security" to which section 2(2) refers cannot have the same meaning which the term "security" is given in section 2(I). If it did, it would rob the last sentence of section 2(2) of any limiting effect. What meaning the phrase does have can only be interpreted in the light of the legislative history which indicates that the purpose of section 2(2) was

... to exclude the ordinary noncommercial trust but to include that type of organization, commonly known as a "business trust" or a "Massachusetts trust," which without resort to the device of incorporation, is used to achieve many of the purposes of the ordinary business corporation. ${ }^{24}$

The language "evidenced by a security" might perhaps be read to require some tangible token of the beneficiary's interest in the trust or that such interest be transferable. ${ }^{25}$ However, it is clear that a business trust could be operated without issuing certificates $^{2 B}$ and without permitting the transfer of interests in the trust. Thus, either or both of these readings would frustrate attainment of the congressionally expressed purpose of the language. A line which may be drawn to achieve the expressed legislative purpose is one suggested by Professor Scott in his treatise on Trusts. He states that one useful classification of the principal purposes for which trusts are created is "a general division into trusts created for the purpose of distributing the bounty of the settlor, and trusts created for business purposes."27 Although there may have been a time when it was acceptable to view the creation of a pension plan by an employer for the benefit of his employees as a gift to them,

${ }^{24}$ H.R. REP. No. 85, 73d Cong., Ist Sess. II (1933).

${ }^{25}$ Beneficial interests in personal trusts are transferable unless such interests are expressly made inalienable by the terms of the trust or by statute or unless the interest is such that only the beneficiary himself can enjoy it (a trust for his personal support) or that the beneficiary has nothing to enjoy other than what the trustee in his uncontrolled discretion' gives him. 2 Ausris W. Scotr, THE LAW of Trusrs $\$ \$ 132,154-55$ (2d ed. 1956). If transferability of interests were the test, most personal trusts would be considered as issuing securities.

${ }^{28}$ The terms of any trust (including a definition of the interest of each beneficiary in the trust) will typically be embodied in a document of some kind. If the "tangible token" can be construed to include such a document, only oral trusts would be excluded by the limiting language of $\$ 2(2)$ of the Securities Act. The Comptroller of the Currency's Regulation 9, $\$ 9.18(\mathrm{~b})(\mathrm{r} 3)$ prohibits a bank commingled fund from issuing "any certificate or other document evidencing a direct or indirect interest in such fund in any form." The interest of the participants in the commingled fund is evidenced by a book entry maintained by the bank. If the language quoted from Regulation 9 represents the correct construction of "tangible token," a mutual fund such as Massachusetts Investors Trust could avoid having to register its shares by not issuing certificates and keeping track of investor interests by book entries and informing its shareholders of the amount of their interests by periodic reports.

${ }^{27} 2$ Scorr, Trusts $\$ 59$, at 514 (2d ed. 1956 ). 
that time has passed. ${ }^{28}$ Much more appropriate is the characterization of the Senate Labor Committee, in its report on the Federal Welfare and Pension Plans Disclosure Act:29 "Regardless of the form they take, the employers' share of the cost of these plans or the benefits the employers provide are a form of compensation." ${ }^{30}$ Accordingly, where, as in a pension trust, the trust is created in connection with an employment relation or where, as in a commingled fund, the trust is created as an investment medium by a person in the investment management business, the trust is created for business purposes and is not non-commercial.

Where the pension plan does not involve a trust but is funded solely by insurance contracts (other than variable annuities) which qualify as exempt securities under section 3(a) (8) of the Securities Act, the Commission has indicated that the plan does not involve the issuance of a security so long as the plan administrator does not have discretion to invest employee contributions in something other than such exempt contracts. ${ }^{31}$ However, if the insurance contracts are held in a trust it would seem that a security would be involved.

Because of the no-sale theory which the Commission has adopted and which is described below, the Commission has never had to decide whether an unfunded plan (i.e., a plan where the employer simply makes pension payments on a pay-as-you-go basis out of the assets of the business to employees who have retired) involves the issuance of a security. Logically, it is hard to understand why a distinction for the purpose of defining the existence of a security should be made between a plan, the obligations of which are funded in a separate pool, and a plan, the obligations of which are "funded" in the employer's business." If the employer's plan to pay

${ }^{28}$ See HarbRecht, op. cit. supra note 7 , at 177, $18 \mathrm{x}-83$; Note, Legal Problems of Privatc Pension Plans, 7o Harv. L. REv. 490, 494-95 (1957).

${ }^{29} 72$ Stat. 997 (1958), as amended, 29 U.S.C. $\$ \$ 30 I-09$ (Supp. IV, 1963) [hereinafter cited as the Federal Welfare and Pension Plans Disclosure Act].

${ }^{30}$ S. REP. No. 1440, 85th Cong., 2d Sess. 4 (1958) [hereinafter cited as the KENNEDY REPORT].

${ }^{31} 1941$ Hearings at 897 . The Commission views the recently developed deposit administration group annuity contracts which utilize the segregated account method of funding and have many of the characteristics of a variable annuity or of a trusteed plan as being subject to the federal securities laws. The Commission takes the position that the segregated account is an investment company for purposcs of the Investment Company Act and involves the issuance of a registrable security within the meaning of the Securities Act. When the segregated account is used only for employec retirement plans which qualify under $\$ \S 40 \mathrm{I}-04$ of the Internal Revenue Code, the account has, for all substantive purposes, the same characteristics as a qualified trust which is exempted from the Investment Company Act by $\S_{3}(\mathrm{c})\left(x_{3}\right)$ of the act. The Commission has accordingly exempted such accounts from the Investment Company Act and from the registration provisions of the Securities Act if they meet certain conditions. Sce Rule 3c-3, I7 C.F.R. \$270.3C-3 (1964); Rule 156, I7 C.F.R. \$230.156 (1964). Apparently the Commission does not find an investment company or a registrable security to exist in a conventional deposit administration group annuity contract which does not involve a segregated account. For a general discussion of deposit administration group annuity contracts, see DAN M. McGill, FundaMcsntals of Private Pensions 156-78 (2d ed. 1964). See p. 821 and note 129 , infra for a discussion of Rule r56 and Rule 3c-3.

${ }^{32}$ Compare In the Matter of Maritime Corporation, 9 S.E.C. 906 (194r). This case involved a corporation organized to hold and invest the surplus funds of a business corporation pending utilization of those funds in the latter's business. The shareholders of the corporation were substantially the same as the shareholders of the business corporation. The Commission held that the corporation was cntitled 
pensions is communicated to his employees and constitutes a binding obligation on him to pay pensions to employees who satisfy the conditions of the plan, he has in substance issued a contract in the nature of a contingent annuity. Such a contract would appear to fall within one or more of the terms "evidence of indebtedness," "certificate of interest or participation in any profit-sharing agreement," or "investment contract" and thus constitutes a security. ${ }^{33}$

III

\section{The Interest of the Employee Participant in a Pension Plan}

The determination that a pension plan involves the issuance of securities does no more than suggest the existence of a possible investor interest which may require some or all of the protections of the federal securities laws. Analysis of the nature of the possible investor interest which exists in an individual case may cause one to decide that it is not the kind of investor interest to which all of the protections of the Securities Act should be applied. At times a decision that such protections should not be applicable has resulted in a determination that a particular interest does not constitute a security. ${ }^{34}$ In this section we shall examine some of the factors which help to determine whether the protections of the Securities Act should be applicable. Our analysis will first focus primarily on the relationship between the plan participant and the plan. Later we shall examine more closely the commingled fund which

to exemption from the Investment Company Act under $\$ 6(\mathrm{c})$ because it was "essentially a private enterprise to which it was not intended" the act should apply.

See also the Commission's position regarding employee savings plans, described in note 45 infra.

${ }^{30}$ This conclusion would seem to be confirmed by the negative implication contained in the $\$ 3(a)(8)$ exemption from the provisions of the Securities Act for insurance contracts issued by an insurance company. However, the House Committee report describing $\S 3(\mathrm{a})(8)$ suggests that, even without the exemption, insurance policies would not be regarded as securities subject to the act. H.R. REP. No. 85, 73d Cong., Ist Sess. I5 (1933); see I Louis Loss, Securities Regulation 497 (2d ed. I96r). At the time the Securities Act was passed, the U.S. Supreme Court had not yet laid to rest the widely prevailing notion that activities of insurance companies were beyond the reach of the commerce clause of the Constitution. United States v. South-Eastern Underwriters Association, 322 U.S. 533 (1944). Nevertheless, there is no evidence that Congress intended to exempt every insurance-type contract issued by any company-whether or not it is an insurance company. The fact that $\$ 3(a)(8)$ describes the type of issuing company with particularity seems to be persuasive evidence that Congress thought that insurance-type contracts issued by companies other than those "subject to the supervision of the insurance commissioner, or any agency or officer performing like functions of any State or Territory of the United States or the District of Columbia" were securities subject to the provisions of the Securities Act.

Commissioner Purcell testified in the I94I Hearings that an employee welfare plan providing for hospitalization benefits or sick benefits does not involve a security. He argued that such plans do not involve the issuance of investment contracts because the payments are not made with a view to their being invested and earning a return for the employees. I94I Hearings 896. Presumably he would have taken the same view of welfare plans providing for benefits in the event of unemployment, death, or disability. However, it is hard to distinguish the expectation of return under these plans from the expectations of return under any contract which pays a determinable benefit on the happening of a described event. See id. at 922 (testimony of R. V. Fletcher, General Counsel for the Association of American Railroads). As long as such contracts are not exempt under $\$ 3(a)(8)$ of the Securities Act, they would appear to fit the literal definition of a security.

${ }^{34}$ See the discussion in note 33 supra, concerning interests in certain welfare plans which have been considered not to constitute securities even though the statutory language seemed to argue for a different result. 
may be used as the investment medium for a pension plan and the relationship between the commingled fund and both the employer setting up the plan and the participants in the plan.

Let us turn to the interest of the exuployee who participates in a pension plan. He knows that one element of the compensation in his present job is coverage under a pension plan. At a minimum, he should know the terms of that pension plan. He should know what contributions are made to the pension plan, what benefits are payable and what he must do in order to qualify for those benefits. If the pension plan is one which qualifies for favorable tax treatment under section 4or of the Internal Revenue Code of 1954, he will get that information. The employer must apprise his employees of the establishment of a qualified plan and its salient provisions. ${ }^{35}$ The Internal Revenue Service suggests that this requirement may be most satisfactorily met by furnishing each employee with a copy of the plan. ${ }^{36}$ Furnishing the employees with a copy of the formal plan (which may in many cases be a complex legal document) does not necessarily satisfy Securities Act disclosure standards which require that the facts must be disclosed in a form which is clearly understandable to the ordinary investor. ${ }^{37}$ Many employers recognize that the plan, itself, may be hard for their employees to understand and they furnish a booklet (either instead of the plan or to accompany the plan) which explains in simple language the plan's main features. This is acceptable to the Internal Revenue Service so long as the employees are either given a copy of the plan or are told where they may inspect a copy. ${ }^{38}$ No similar requirement for telling the employees about the terms of the pension plan is imposed under the Internal Revenue Code when they participate in a plan which does not qualify for favorable tax treatment under section 4 or of the Code.

Although all the participants in an H.R. xo pension plan would receive information about the terms of the plan under this procedure (since this is a plan which qualifies for favorable tax treatment under section 40 I of the Internal Revenue Code), there is no requirement imposed under the Code that such participants receive any accounting concerning the administration and operation of the plan or about the success of the plan in meeting its objectives. However, such information seems important-especially in those situations, typical in H.R. xo plans, where the level of benefits is variable and depends on the quality of the investment management of the pension plan assets. Even in those cases where the pension plan pays a fixed level of benefits, the employee seems entitled to receive enough information to know whether he can properly rely on receiving his pension-to know, for example, whether the fund has received sufficient contributions or has been managed in a way which will permit it to pay such benefits.

Although it appears that the type of disclosure which the Securities Act requires

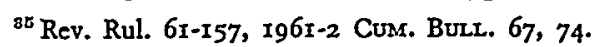

${ }^{30} \mathrm{Ibid}$.

${ }^{37}$ See In the Matter of Universal Camera Corp., I9 S.E.C. 648 (I945).

${ }^{\text {as }}$ Rev. Rul. 6r-157, 196r-2 Cum. Bull. 67, 74 . 
would be useful in protecting the interests of the employees in the plans covering them, the Commission does not today require such disclosure in any but a limited class of cases. In analyzing the Commission's position, it is useful first to consider those plans which do not involve voluntary contributions on the part of the employees-i.e., where only the employer makes contributions to the plan on behalf of the employees, or where, if the employees do contribute, their contributions are a compulsory aspect of their employment. The Commission has taken the position that the Securities Act does not apply to such plans because there is no "sale" or "offer" for sale of the security. Section 2(3) of the Securities Act defines these terms as follows:

The term "sale" or "sell" shall include every contract of sale or disposition of a security or interest in a security, for value. The term "offer to sell," "offer for sale," or "offer" shall include every attempt or offer to dispose of, or solicitation of an offer to buy, a security or interest in a security, for value....

A sale or offer within the meaning of this definition must be present before the provisions of the Securities Act are called into play. The Commission's position is not premised on the theory that the interest in the pension plan was disposed of without value or consideration in the common law sense. ${ }^{39}$ Indeed, as we have pointed out above, the employer's contributions to the plan are a form of compensation. This is even clearer in those cases where the employee is required to turn back a portion of his compensation to the plan. Rather, the Commission's view is premised on the ground that there is no offer or sale in the securities law sense because "there is no element of volition on the part of the employees whether or not to participate and make contributions." interest in the pension plan-the only way he can refuse to make a purchase is by quitting his job. In short, the Commission's position is that if the employee has no real choice with respect to the medium in which his funds are invested there

${ }^{30}$ At an earlier time it might have been possible to premise an exclusion for pension plans not involving a voluntary contributory aspect on the ground that the employer was making a gift to his cmployces. Ganson Purcell, then Chairman of the Commission, articulated that argument in the I94I Hearings. rg4I Hearings 896 . This view was in accord with many court decisions dealing with the question whether an employee had an enforceable contract right to receive a pension that had been promised to him but which contained a disclaimer of liability clause. See HarBrecht, op. cit. supra note 7, at I8I-83; Note, Legal Problems of Private Pension Plans, 7o Harv. L. REv. 490, 493-503 (1957). A major landmark of the shift that has been occurring toward the view that employee pensions and the funds contributed to pension and welfare plans are wages was the decision in Inland Steel v. NLRB, 77 N.L.R.B. I (1948), enforcement granted, I70 F.2d 247 (7th Cir. 1948), cert. denied, 336 U.S. 960 (1949), holding that pension and retirement plans are a proper subject matter for compulsory collective bargaining under the Taft-Hartley Act on the ground that such plans realistically viewed are part of the entire wage structure. See HARBRECHT, op. cit. supra note 7, at 163-65.

${ }^{10}$ Op. SEC Ass't Gen. Counsel (I94I), I CCH Fed. SEC. L. Rep. I 223I.2I. The Commission's interpretation is not an easy one to fit in with the language of the statute which merely requires that there be a "disposition of a security ... for value" (emphasis supplied). The gloss which the Commission has placed on the statutory language seems proper, however, in light of the scheme of the actto arm persons solicited in connection with a distribution of securities with sufficient information to enable them to determine whether they should purchase the security. 
would be only a limited usefulness in requiring disclosure to him of information concerning the operation and administration of the pension plan.

This articulation is similar to the one which underlies Rule 133 of the General Rules and Regulations under the Securities Act ${ }^{41}$ which provides that, for the purpose of section 5 of the Securities Act only, ${ }^{42}$ a no-sale transaction shall be deemed to be involved with respect to the shareholders of a corporation when their securities are exchanged or modified pursuant to a reclassification, merger, consolidation or sale of assets in exchange for stock in another corporation if the law of the state of incorporation or the corporation's articles of incorporation authorizes the approval of the transaction by majority vote of the shareholders and such vote binds all shareholders of the corporation whose stockholders are voting except for the statutory appraisal rights of dissenters. In other words, since the transaction may be forced upon shareholders they have no chance to make individual investment choices and no purpose is served in requiring disclosure to them of the investment oriented information which the Securities Act otherwise contemplates should be made available.

The Commission's position under Rule 133 has been criticized on the basis that it does not give sufficient recognition to the part which individual consent plays in the process of statutory reorganization. ${ }^{43}$ A similar criticism can be made with respect to the Commission's view of the role individual employees may play in influencing the operation and administration of pension plans in which they participate. If the information disclosed concerning the pension plan suggests the existence of a question regarding the protection of the employees' interests, in many cases pressure may be brought to bear on the employer to rectify the situation. The disclosure required by the Securities Act not only fulfills an immediate function of providing information which permits an investor to make an informed choice among various investment media; but it also has the related effect of making persons adhere to a higher standard of conduct than they might adhere to if they were not sure that their conduct would be exposed to the harsh glare of publicity. ${ }^{44}$ Finally, there is another ground on which the Commission's no-sale approach might be criticized. Pension and profit-sharing plans and other fringe benefits have become an increasingly important aspect of the total wage structure. The Commission's position regarding the usefulness of Securities Act disclosures may give insufficient weight to the importance which retirement and other plans may have in affecting job choices by employees.

${ }^{11}$ I7 C.F.R. $\$ 230.133$ (1964).

${ }^{42}$ Rule $\times 33$ was carefully drafted to exempt the transactions described from only the registration provisions of the Securities Act. The Commission takes the position that such transactions remain subject to the anti-fraud provisions of the Securities Act and the Securities Exchange Act of 1934, 48 Stat. 881 (1934), as amended 15 U.S.C. $\$ \$ 78 \mathrm{a}-$ to hh-l (1958), 15 U.S.C. $\$ \$ 78 c-s$ (Supp. IV, 1963) [hercinafter cited as Securities Exchange Act]. It is not clear whether the Commission's no-sale interpretation with respect to pension plans has an equally limited scope.

${ }^{43}$ See Note, 47 CAz. L. Rev. I12, 115 (1959).

14 See Cary, The Direction of Management Responsibility, 18 Bus. LAw. 29 (1962). If the offering of interests in a pension plan need not be registered, the plan will not under present law become subject to the periodic disclosure and reporting requirements of the Securities Exchange Act. 
Whatever the validity of the no-sale approach of the Commission in those situations where the employee has no individual say with respect to the investment of part of his compensation in a pension plan, it has no validity where the employee is completely free to choose whether or not he wishes to invest in the pension plan. Such a situation will be common with respect to H.R. Io pension plans. Here the employee is in precisely the same position as any investor who has some money available to place in any of a number of competing investment media. This is precisely the kind of situation for which it was thought necessary to erect the Securities Act. Nonetheless, the Commission takes the position that "no question will be raised with respect to the registration of participations in a voluntary contributory pension, profit-sharing, or similar plan that does not invest in the securities of the employer company in an amount exceeding the company's contribution." This position was contained in letters, dated May 12, 1953, to Commerce Clearing House, Inc. and Prentice Hall, Inc. and was reaffirmed in August I962. ${ }^{45}$ No rationale for the Commission's no-action position regarding plans having such voluntary, contributory features is articulated in these letters.

The position can, of course, be justified. The employer who creates the pension plan is not in the pension plan business and for a great many employers it would be burdensome to have to prepare a registration statement in connection with the

"Letter dated Aug. I, 1962, from the Chief Counsel of the Division of Corporation Finance to Commerce Clearing House, Inc. These letters are reproduced at I CCH FED. SEc. L. REP. I 2231.22. The Commission has not always taken this position. Prior to 1951 companies were advised that plans under which any contributions were invested in employer stock had to be registered, and that form S-I was the appropriate form to use.

It should be noted that the Commission's position regarding plans which must presently be registered applies not only to plans involving the purchase through employee contributions of employer stock but also to certain savings plans pursuant to which the employee voluntarily leaves a portion of his wages in a demand account with the employer who agrees to pay interest on the amounts left with him. Such plans give the employees a creditor's claim against the employer's assets and thus involve the issuance and sale by the employer of a security in the form of an "evidence of indebtedness" within the meaning of $\S 2(\mathrm{I})$ of the Securities Act. The Commission considers that the exemption for short-term commercial paper provided by $\S 3(2)(3)$ of the act is inapplicable to such plans. Cf. SEC Securities Act Release No. 4412, Sept. 20, 196r. Although questions had been raised by the Commission staff about such plans prior to 1941 , see 1941 Hearings 967 , a no-action position was taken with respect to them until after the adoption of Form S-8 in I953. However, the first registration of such a plan did not take place until r962. Such plans must also comply with the Trust Indenture Act of 1939.

It should be pointed out, however, that not all things which technically might be analyzed as "evidences of indebtedness" are in fact considered "securities" within the meaning of the Securities Act. For example, the Commission refused to accede to a request that it treat retail trading stamps redeemable in' cash or merchandise as "evidences of indebtedness" within the meaning of $\S_{2}(\mathrm{I})$ of the Securities Act. The Commission stated that: ". . . the same argument could be made as to streetcar tokens, meal tickets, Christmas gift cerificates, box tops, railroad or theatre tickets, and others too numerous to mention. The legislative history and other provisions of the statute indicate that the Congress did not intend to include such items within the scope of the statute." SEC Securities Act Release No. 3890 , Jan. 21, 1958. In addition, the Commission has taken the position that the travelers' checks issued by the American Express Company are not securities within the meaning of $\$ 2(I)$. See Leighton $v$. SEC, 22 I F.2d 9 I (D.C. Cir.), cert. denied, 350 U.S. 825 (I955). Customers' credit balances left with broker-dealers have not been treated as securities, whether they bear interest or not. Merchants' trade accounts payable usually do not constitute securities. The dividing line in these areas between interests which are securities and those which are not might be described as one between media created primarily for exchange and media created primarily for savings or investment. 
operation of their pension plans. ${ }^{46}$ The consequences of imposing Securities Act responsibilities upon the employer might result in causing him not to permit any of his employees to make pension plan contributions toward their retirement.

The Commission's position that both the employer's stock and the interests in the plan pursuant to which it is issued must be registered where the employer's stock is the investment medium for employee contributions fits in with this rationale. The employer, in that case, has a direct financial interest in the solicitation of the employees' contributions and it is not unfair to make him assume the same burdens which corporations typically assume when they go to the public for financing. ${ }^{47}$

The responsibility of the Commission to apply the protections of the Securities Act to plans for the purchase by employees of employer stock was made clear in I934 in the course of the adoption of the Securities Exchange Act. A provision had been added on the floor of the Senate to the bill that became the Securities Exchange Act, which would have amended section $4(\mathrm{r})$ of the Securities Act by adding the following words:

As used in this paragraph, the term "public offering" shall not be deemed to include an offering made solely to employees of an issuer or of its affiliates in connection with a bona fide plan for the payment of extra compensation or stock-investment plan for the exclusive benefit of such employees. ${ }^{48}$

The amendment was eliminated by the Conference Committee at the insistence of the House conferees. The report of the Conference Committee said this was done "on the ground that the participants in employees' stock investment plans may be in as great need of the protection afforded by availability of information concerning the issuer for which they work as are most other members of the public."190

the burdens of registration would of course be particularly great for the smaller employer and smaller plan. Section 3 (b) of the Securities Act, however, gives the Commission power to exempt plans from the registration provisions of the act if the employees' contributions do not exced $\$ 300,000$ per year. Many plans, including most H.R. Io plan's, would be able to qualify for such an exemption. The Commission has never adopted a rule under $\S 3$ (b) of the Securities Act giving a blanket exemption to pension plans meeting the $\$ 300,000$ test. The only exemption presently available to pension plans under $\varsigma_{3}(b)$ is provided by Regulation $A$. On the other hand, concern for the smaller employer at the time of the adoption of the Welfare and Pension Plans Disclosure Act in 1958 led to the creation of an exemption from the act for any plan which did not cover more than 25 employees. The r962 amend. ments to the Welfare and Pension Plans Disclosure Act expanded on this principle by cxempting plans covering less than 100 participants from the annual reporting though not the registration provisions of the act.

${ }^{47}$ Once it is assumed that the employer's stock is being offered to the employees and is, therefore, subject to the registration statement requirement because of the lack of a private offering, it is not a far (or burdensome) step to require the employer to include information about the pension plan along with the information concerning the stock. Form S-8, promulgated on June 16, 1953, was specially designed to call for information with respect to both the stock and the plan.

$\triangle 878$ CONG. REC. 8708 (1934).

${ }^{48}$ H.R. REP. No. 1838, 73d Cong.s 2d Sess. $4 \mathrm{I}$ (1934). During the discussion on the Senate floor of the Conference report, the Senator who had sponsored the $\S_{4}(\mathrm{I})$ amendment regarding cmployee stock investment plans was told that one of the reasons the Conference Committee struck the amendment was that a majority of the conferees thought that offerings limited to employees could not be "public offerings" in any event. 78 CoNG. Rec. xor $81-82$ (1934). Such a view would of course be inconsistent with the statement contained in the Conference Committee report which is quoted in the text. 
The Commission has consistently required the registration of voluntary, contributory stock purchase plans.

Although the Commission's no-action position with respect to other voluntary contributory plans can be justified along the lines discussed on pages 809 to $8 \mathrm{ro}$, complete understanding of the Commission's position can only be achieved in light of a review of the efforts made in the legislative program of I94I to deal with pension plans. As part of that program, the Commission proposed one amendment to the Securities Act which would have exempted from the act employee plans meeting certain rigid conditions, ${ }^{50}$ and a second amendment which would have given the Commission the power by rule to exempt, for purposes of section 5 , interests in any other employee "savings, pension, profit-sharing or other employees' benefit plan."51 Although the entrance of the United States into the Second World War, which occurred during the House hearings on the Commission's program, caused the program to be dropped without action being taken by the Congress, the reception given to the Commission's position regarding employee plans during the House hearings could hardly be described as enthusiastic. No industry witness appeared to testify on behalf of the proposed amendments; but several industry witnesses testified against them. This was not because they thought that the provisions of the Securities Act should be applied to employee plans. On the contrary, they said that the Securities Act had not been intended to cover any kind of employee plan except stock purchase plans; and they argued that Congress should not adopt the amendments because adoption would have the effect of sanctioning the Commission's construction of the act and would thus cause the act to become applicable

The Supreme Court in Securities and Exchange Commission v. Ralston Purina Co., 346 U.S. IIg (I953), said in a footnote that the statement contained in the Conference report was "entitled to more weight" than the statements made in the debate on the floor. 346 U.S. at 126 n.I3.

${ }^{20}$ The assets had to be held in a trust specifying that the assets and income could be used only for the exclusive benefit of the employees; the employer had to be obligated to make regular cash contributions; $75 \%$ of the assets had to be held in cash, bonds, notes, debentures, insurance contracts, bank stock or government securities; none of the assets could be invested in securities of the employer; the interests of the employees relating to their own contributions had to be nonforfeitable; each participant had to receive a summary of the plan and an annual report; a copy of the trust instrument had to be made available to each participant upon request; and the summary of the plan and a copy of the trust instrument and each annual report had to be filed with the Commission. 194I Hearings 908.

${ }^{52}$ See 1941 Hearings at 907, 950. On the other hand, the Commission opposed a bill introduced by Congressman Paddock which would have exempted from the definition of "security" in the Securities Act any plan which qualified under $\$ 165$ (now $\$ 40 \mathrm{I}$ ) of the Internal Revenue Code. The Commission opposed the bill on two grounds. First, that the restrictions imposed by $\$ \pi 65$ were not sufficient to justify exemption under the Securities Act for all qualified plans. (This is an interesting position in view of the fact that the Investment Company Act did contain an express exemption for all qualified plans and this had apparently been acceptable to the Commission.) The second was that any exemption given to employee plans under the Securities Act should apply only to the registration provisions of the Act: Such plans should remain subject to the anti-fraud provisions. 1941 Hearings 9I9-20.

The Paddock bill would also have exempted from the definition' of "security" in the Securities Act any interest in an employee's savings account plan pursuant to which the employee voluntarily leaves part of his wages in a demand account with the employer who guarantees principal and interest on the amounts retained. Id. at 975-76. The Commission also opposed this exemption. See id. at 919-20. As indicated in note 45 supra, the Commission presently requires such plans to be registered. 
to any employee plan which did not meet the terms of any exemption granted pursuant to the amendments. Nothing said by the House Committee members during the hearings was calculated to give the Commission much comfort about applying the Securities Act to plans other than stock purchase plans. ${ }^{52}$

One other reason for the Commission's reluctance to compel registration under the Securities Act of voluntary contributory plans other than stock purchase plans is worth mentioning. A great variety of plans and benefits exist and the lines that can be drawn between welfare plans and pension plans, funded plans and unfunded plans, voluntary contributory plans and compulsory or noncontributory plans, insured plans and trusteed plans, are not always very meaningful. Opportunities for abuse can exist in any one of these types of plans. Consequently, application of the registration provisions of the Securities Act to only one of the many varieties of plans (i.e., to only trusteed retirement plans having a voluntary contributory aspect) would go only a short distance toward protecting the interests of participants in welfare and pension plans generally. Conversely, application of the provisions of the Securities Act to one type of plan would make it difficult to explain why other types of plans should not also be subject to the act. If all such plans had to be registered, the Commission staff would have received a flood of registration statements-a flood which they were not equipped to handle and for which it would have been difficult to secure congressional appropriations.

The Commission has never embodied its present "hands-off" policy concerning pension plans in the form of an interpretative or exemptive rule. Employers and their plans, therefore, do not enjoy the insulation from liability which section I9(a) of the Securities Act gives to persons who omit to do acts in good faith in conformity with a Commission rule. Although it can be argued that the Commission's "no-sale" interpretation in connection with noncontributory or involuntary plans need not as a practical matter be incorporated in a rule (since it is unlikely that a court would refuse to apply this interpretation if urged to do so by the Commission), this cannot be said with respect to the Commission's no-action position concerning voluntary contributory plans. Thus, the possibility remains that, at least with respect to those plans which are relying on the Commission's no-action position, the plan and its related trust and the employer are subject to liability under section I2( $x$ ) of the Securities Act.

Section I2(r) provides that any person who offers or sells a security without complying with the registration and prospectus provisions of section 5 of the act can be forced by the purchaser of the security to rescind the transaction. This liability, however, is probably more theoretical than real in the context of the average pension

\footnotetext{
"As one point Congressman Wolverton said to Commissioner Purcell: "Well, the more you talk -.. the more I am impressed with the thought that the subject is so big, of such a character, and covers a field so wide that it should be a matter of special legislation, if it is necessary, and not to be tacked on to the Securities Act like a wart to something that was never intended to apply to it. It just secms to me that you are driving something in that never was in contemplation when we passed this Securities Act." 2941 Hearings 9r3.
} 
or welfare plan. For one thing, section 13 imposes a one-year statute of limitation on any action brought to enforce a liability under section $\mathrm{I2}(\mathrm{I})$. Thus, the employee's rescission right in the pension or welfare plan context would only apply to any contribution made by him to the plan within the one-year period preceding the commencement of suit. The contribution made by an employee in any single year will usually be so small that he would have little motivation to want to exercise any rescission right he might have. Moreover, in many cases, exercise of the rescission right might result in the employee losing benefits under the plan that are as valuable as the recission right or even more valuable than that right..53 Further, it is likely that few employees or pensioners would want to bring suit against their employer or their plan.

Even though the section 12 (I) liability is, therefore, largely theoretical for most pension or employee benefit plans, it would nonetheless be desirable to eliminate it entirely for those plans which the Commission has decided ought not to be required to comply with section 5 of the act. There are some steps in this direction which the Commission could take under its present statutory authority. The Commission could, to begin with, incorporate its no-sale position in an interpretative rule under the Securities Act. Such a rule could be adopted under either section 2(3) of the act (in which case it would apply for all purposes under the act), or section 5 of the act (in which case it would apply for purposes of that section only). The Commission could also adopt a rule under section 3 (b) of the act granting an unconditional exemption from the provisions of section 5 of the act for voluntary, contributory plans which do not invest in securities of the employer in an amount in excess of the employer's contributions. The exemption which can be granted under section 3 (b) is limited by the present provisions of the act to plans where the employees' contributions do not exceed $\$ 300,000$ annually. Thus, before the Commission's noaction position can be incorporated in a rule applicable to all voluntary contributory plans, the act would have to be amended to remove the $\$ 300,000$ limitation for securities issued by pension and other employee benefit plans. Such an amendment is identical to the one proposed by the Commission in its I94I legislative program. ${ }^{54}$

Even if the above exemptions were granted with respect to the liability imposed by section I2(I) of the Securities Act, possible liability would, nonetheless, remain under the anti-fraud provisions of sections I2(2) and I7 of the Securities Act and section ro of the Securities Exchange Act. The employer (or other plan sponsor such as a union), as a controlling person ${ }^{55}$ or underwriter or seller, and the plan and its related trust, if any, as an issuer, would be liable under these sections if they

${ }^{53}$ The effect of an employee's attempt to rescind is by no means clear. For example, in a case involving medical or death benefits can an employee rescind after he has enjoyed coverage for the year? Where the plan provides for matching employer contributions, will the employee's rescission permit the employer to take back his contribution-or, if the employer cannot take back his contribution, will the benefit to the employee attributable to the employer's contribution nonetheless be lost to him? it See p. 8I I supra.

¿E Securities Act $\S 15$; Securities Exchange Act $\S 20(a)$, (b). 
were responsible for any untrue or misleading statement made in connection with an "offer" or "sale" (for purposes of these sections) of any interest in the plan which constitutes a "security." Since these anti-fraud provisions do not impose an undue burden on anyone, there is no reason why they should not remain as remedies available to employees for use in cases where fraud of the kind covered by these sections has been committed.

\section{A. Investment Company Act Considerations}

Perhaps, since a large portion of the contributions made by and on behalf of employees are not voluntary and therefore permit the employees no effective choice with respect to their disposition, the disclosure protections of the Securities Act are not so vital for the protection of employee participants in benefit plans. However, the protections of the Investment Company Act would appear peculiarly appropriate in this situation. The participants in a benefit plan are normally locked into their investment to a much greater extent than the ordinary holder of mutual fund shares. Thus, those provisions of the act which give investment company shareholders some voice in the management of the company's assets, provide for one or more persons to act as a watchdog of the shareholders' interest, and spell out certain substantive rules which require the investment company's affairs to be managed solely in the interests of the shareholders seem to be of special significance to such participants.

However, the value of the Investment Company Act in this area has never really been tested. Fewer than twenty employee plans have been registered under the act. $^{56}$ The small number of registrations is not due to any doubt that a pension or other employee benefit trust which invests in securities fits the basic definition of an investment company. It is an issuer which is engaged primarily in the business of "investing, reinvesting or trading in securities." However, most pension trusts

\footnotetext{
${ }^{58}$ Many of the plans which have registered have been plans for investment in the employer company's stock.

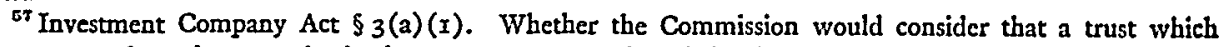
is empowered to invest only in insurance contracts issued by insurance companies is an investment company for purposes of the Investment Company Act is not clear. It seems likely, however, that the Commission would hold that such insurance contracts do not constitute securities (see the discussion supra note 33) for purposes of the Investment Company Act and that the trust does not constitute an investment company. In addition to the definition of investment company which is contained in $\S 3(a)(1)$ of the act and quoted in the text above, $\S_{3}(\mathrm{a})(2)$ of the act contains a second definition of an investment company. It states that an investment company includes any company which engages in the business of issuing face-amount certificates of the installment type. Although the employee's interest in a pension or welfare plan may arguably sometimes fit the language which is used in $\$ 2$ (a) (15) of the Investment Company Act to define a face-amount certificate of the installment type, the definition was not written with such benefits in mind and the Commission is unlikely to determine that such benefits come within the meaning of the definition.

An employee benefit plan which invests solely in government bonds which qualify as exempted securities under the Securities Act would constitute an investment company under the first definition of an investment company mentioned above. Such bonds are clearly securities. However, a trust which invests primarily in notes secured by mortgages would be able to qualify for the exemption contained in section $3(c)(6)(C)$ of the Investment Company Act. Aside from pension plans, employec welfare plans funded with securities would also appear to be investment companies. Welfare plans would not qualify
} 
have been exempted from complying with the provisions of the Investment.Company Act by section 3(c) (13) which exempts from the definition of investment company "any employees' stock bonus, pension, or profit-sharing trust which meets the conditions of section 165 of the Internal Revenue Code, as amended." This exemption was not contained in the original draft of the Investment Company Act, but appeared for the first time in the final version of the act. The legislative history does not indicate the reasons for including this exemption." However, the "conditions of section 165 " (now section 401 of the Internal Revenue Code) assure some protection to participants in pension trusts. In order to meet the conditions, the pension trust must be established for the exclusive benefit of the participants and no part of its assets may be used by or revert to the employer. In addition, section 503 (c) of the Code prohibits certain transactions between the pension trust and any person, such as the employer, who has made a substantial contribution to the trust. Since the employer is prevented by section 4 or from benefiting from the administration and operation of the pension trust, and since it can be assumed that he is interested in assuring that his contributions to the plan provide a maximum amount of benefit to his employees, the danger of the trust being administered in a way which disregards the interests of the employees is minimized. This would be particularly true with respect to those pension trusts which provide fixed benefits since the employer in those situations would have an added incentive to keep his costs down by seeking the most efficient administration of the trust. As a result imposing the protections of the Investment Company Act may not provide sufficient additional benefits to justify the cost of requiring compliance with the act. The reluctance to impose the cost of compliance with the Investment Company Act on a person who is not in the securities business, but who has decided to create a pension or other benefit plan for his employees, is reflected by section 6(b) of the act which specifically provides that the Commission shall grant an exemption from the act to any employees' security company "if and to the extent that such exemption is consistent with the protection of investors." The Commission has granted exemptions to approximately twenty companies under this provision. Almost all of the exemptions which have been granted have related to certain specific sections of the act: The Commission has preferred to avoid granting blanket exemptions from all of the provisions of the act. The

for the exemption contained in section 3 (c)(I3) of the Investment Company Act. However, no welfare plans have been registered under the Investment Company Act.

It should be noted that funded plans can become subject to the Investment Company Act even if they do not contain a voluntary contributory element. No "sale" or public "offer" is necessary in order to bring the act into play.

DS The original draft of the act did contain the provisions of the present section 6(b) allowing the Commission to grant exemptions for "employees' securities companies."

${ }^{50}$ Section 6(b) of the act uses the mandatory word "shall," as distinquished from the permissive "may" which is used in $\$ 6(\mathrm{c})$. Section $6(\mathrm{~d})$ of the act also uses the word "shall." Compare the description of $\$ 6($ b) by SEC counsel David Schenker in the Senate hearings on the act, Hearings on S. 3580 Before a Subcommittee of the Senate Committee on Banking and Currency, 76 th Cong., 2d Sess. 196-97 (1940), with the statement made in In the Matter of Executives Investment Trusts-Elfun Trusts, I4 S.E.C. 826,829 n.12 (I943). 
exemptions have been granted on the basis of an ad hoc determination in each case and the Commission has not always clearly articulated the standards which it has applied in granting and refusing exemptions requested by such companies. ${ }^{00}$

\section{B. The Federal Welfare and Pension Plans Disclosure Act}

The hands-off policy of the Commission and the limited applicability of the federal securities laws to the many varieties of welfare and pension plans left such plans largely unaffected by any disclosure or regulatory legislation at the federal level which was designed to protect employee interests. ${ }^{61}$ As the importance of welfare and pension plans grew during and after World War II it was perhaps not surprising that some abuses regarding such plans developed. Beginning in 1954 a Senate subcommittee, at the suggestion of President Eisenhower, undertook the first of a series of investigations of welfare and pension plans. These uncovered various abuses-primarily related to welfare plans and to practices surrounding the use of insurance. The investigations culminated in the adoption in 1958 of the Federal Welfare and Pension Plans Disclosure Act.

Initially the Senate subcommittee recommended that the Securities and Exchange Commission administer the act because "of its organizational set up and its established success in the administration of disclosure type statutes." ${ }^{\text {"22 }}$ The Commission was not enthusiastic about undertaking this new task. It felt that the plans subject to the act were inseparably intertwined with labor management relations and that the abuses uncovered had their main effect not in the capital market but upon economic areas in which the Commission did not possess expertise. In addition, the Commission was also worried about the number of plans which would be registered under the act. ${ }^{63}$ On the other hand, the Department of Labor asked for the authority to administer the act, and was supported in this request by the Eisenhower Administration. ${ }^{64}$ It ultimately received that power.

The Federal Welfare and Pension Plans Disclosure Act as initially passed by the Senate was primarily a disclosure statute but it contained certain minimal regulatory provisions and gave limited administrative powers to the Department of Labor. As finally passed by the Congress in 1958 , however, the act was considerably watered down. The regulatory provisions and the administrative powers of the Department

${ }^{60}$ The Commission has issued opinions with respect to only four of the applications for exemption which have been filed under $\$ 6(\mathrm{~b})$ : In the Matter of Electrical Securities Corp., Io S.E.C. 648 (I94I); In the Matter of G.E. Employees Securities Corp., Io S.E.C. 652 (194I); In the Matter of Executives Investment Trusts-Elfun Trusts, 14 S.E.C. 826 (1943); In the Matter of The Thrift Plan of Tennessee Gas and Transmission Co., 24 S.E.C. 24 I (1946). Cf. In the Matter of Maritime Corporation, stupra note 32.

${ }^{01}$ Several states have passed statutes similar to the Federal Welfare and Pension Plans Disclosure Act. These statutes will not be discussed in this article.

${ }^{62}$ S. REP. No. 1734,84 th Cong., 2 d Sess. 9 (1956).

${ }^{63}$ Hearings Before the Subcommittee on Welfare and Pension Plans Legislation of the Senate Committee on Labor and Public Welfare, 85th Cong., rst Sess. II9 (I957).

At least one commissioner, Earl F. Hastings, thought that the potential impact of pension plans on the capital market perhaps justified Commission oversight. Id. at rro.

os Id. at 83 . 
of Labor were reduced or eliminated. This more limited act did not satisfy Secretary of Labor Mitchell or President Eisenhower. In signing the act into law, President Eisenhower said he was approving it "because it establishes a precedent of federal responsibility in this area. It does little else. ... If the bill is to be at all effective, it will require extensive amendment at the next session of Congress." 65 The act was in fact amended in 1962 and now contains most of the provisions which had been recommended by the Senate but had been left out of the act as adopted in r958.

The Federal Welfare and Pension Plans Disclosure Act remains essentially a disclosure rather than a regulatory statute. The disclosures which it requires concerning pension plans, however, are not in some respects as complete or as readily available to the employees as those which could be required under the federal securities laws. On the other hand, since the disclosure and regulatory provisions of the act have been designed specifically for pension and welfare plans they call for more information in some areas and are in many respects more appropriate for such plans than the provisions of the federal securities laws.

Section 6 of the act requires that a "description" of any employee welfare or pension benefit plan shall be "published." The description must include a copy of the instrument pursuant to which the plan was established and is operated. ${ }^{66}$ In addition, it must include a description of selected items such as a schedule of benefits to be paid under the plan, the source of the financing and the identity of any organization through which benefits are provided, and the procedures to be followed in presenting claims for benefits and the remedies available under the plan for the redress of claims denied in whole or in part. Section 7 of the act provides for the "publishing" of an annual report. The basic items contained in this report are a description (for the period covered by the report) of the amount contributed to the plan by the employer, the amount contributed to the plan by the employees, and the amount of the benefits paid and the employees covered; a detailed statement of the assets in the plan at the reporting date, "specifying the total amount in each of the following types of assets: cash, Government bonds, non-Government bonds and debentures, common stocks, preferred stocks, common trust funds, real estate loans and mortgages, operated real estate, other real estate, and other assets"; ${ }^{67}$ a statement of the liabilities of the plan; a statement (for the period covered by the report) of the receipts and disbursements of the plan and of the amount of salaries, fees and commissions charged to the plan, to whom and for what purposes they

of See H.R. Rep. No. 998, 87th Cong., xst Sess. 2 (I96r).

oo This requirement is similar to that imposed by Treasury Regulation $\$$ I.40I-I(b) for qualified pension plans.

of The Special Study of Securities Markets recently recommended that the Federal Welfare and Pension Plans Disclosure Act be amended to require pension funds to disclose their holdings of corporate securities by listing each issue rather than just showing the aggregate amount of their holdings in terms of the general categories presently required by the act. Securities and Exchange Commission, Special Study of Securities Markets, H. Doc. No. 95, pt. 2, 88th Cong., Ist Sess. 870 (Ig63). 
were paid; and the type and basis of funding and actuarial assumptions used and the amount of the current and past service liabilities under the plan. The information required in the annual report does not seem to give the participants in the plan a basis upon which to evaluate the investment performance of the plan in those cases where the benefits are variable.

The extent to which the administrator ${ }^{68}$ of the plan must make either the description of the plan or the annual report available to the participants is determined by the requirement that each of these documents be "published." Publication is defined in section 8 of the act. It means that two copies of the plan and the annual report must be filed with the Secretary of Labor who, in turn, makes them available for inspection by the public. In addition, it also means that the administrator of the plan must make copies of the description of the plan and the annual report available for examination by any participant in the plan at the principal office of the plan; and that any participant who makes a request in writing must be sent a copy of the description of the plan and an adequate summary of the latest annual report. Under the Federal Welfare and Pension Plans Disclosure Act, the participant must take the initiative if he is going to get the information to which the act says he is entitled. However, under the federal securities laws a duty is imposed on the distributors of a security to see that the purchaser receives the information which those laws say he ought to have.

In addition to these disclosure provisions, provisions were added by the 1962 amendments to the act which: give the Department of Labor investigatory and enforcement powers and the power to issue regulations; impose record-keeping and retention requirements upon plan administrators; require plan administrators and plan employees who handle property of the plan to be bonded in order to protect the plan against loss by reason of their fraud or dishonesty; ${ }^{80}$ and impose criminal penalties for embezzlement, theft or conversion of plan assets, for making false statements or concealing facts in connection with the disclosure provisions of the act, and for offering or accepting kickbacks or bribes in connection with the plan. The act excludes from its provisions all plans having not more than twenty-five participants and in addition provides that plans having less than 100 participants shall in general be exempt from the annual reporting requirements of the act. No similar automatic exclusions are contained in the federal securities laws. ${ }^{70}$

${ }^{88}$ The term administrator is defined in $55(b)$ of the act as meaning: "( $\left.r\right)$ the person or persons designated by the terms of the plan or the collective bargaining agreement with responsibility for the ultimate control, disposition, or management of the money received or contributed; or (2) in the absence of such designation, the person or persons actually responsible for the control, disposition, or management of the money received or contributed, irrespective of whether such control, disposition, or management is exercised directly or through an agent or trustee designated by such person or persons."

${ }^{\circ D}$ The regulations under the act provide that the bonding requirements shall not apply to banks when acting as trustees for the plans of other employers or to insurance carriers providing benefits under a plan. 29 C.F.R. $\$ 1306.4$ (e) (Ig63).

${ }^{70}$ Section $3(c)(x)$ of the Investment Company Act excludes from the definition of investment company any issuer whose outstanding securities ate owned by less than 100 persons if the issuer is not making and does not propose to make a public offering of its securities. 
One point of particular interest for present purposes is the fact that the Federal Welfare and Pension Plans Disclosure Act has not in general been considered applicable to commingled funds which are used as the funding medium for commingling the assets of two or more separate employee plans. The act is designed to apply at the level of the individual pension or welfare plan-not at the level of the investment medium which may be used to fund the plan. Thus, where an employee pension plan has been funded through a participation in a bank commingled fund, the act simply requires the annual report of the plan to show the amount of its investment in the commingled fund under the general category "common trust funds"71 - just as an investment by the plan directly in investment company shares or individual stocks would be shown under the general categories "common stocks" or "preferred stocks." The extent to which the Department of Labor will extend this same treatment to all of the various kinds of H.R. Io arrangements has not as of the time of this writing, however, been finally determined. The Department presently has under consideration the question whether certain association or other prototype H.R. Io plan arrangements might make the sponsor the "administrator" of the plan, in which case the act would apply at the level of the prototype plan as distinguished from the level of the individual employer.

\section{IV}

\section{The Commingled Fund}

Two of the prime factors in the unwillingness to apply the federal securities laws to protect the interests of participants in pension plans were that to a great extent these participants did not appear to be true investors and that the employer who created the pension plan was not in the pension plan business and that it would, therefore, be inappropriate to saddle him with the costs of complying with the provisions of the federal securities laws. Neither of these factors appears to be relevant in considering whether the federal securities laws should be applied to a commingled fund in which the assets of several pension plans may be invested. In the H.R. Io situation, for example, the employer, like any other investor, has a choice of funding the assets of the plan in any number of investment media. If he has determined on an equity investment, he can choose a bank-sponsored commingled fund, a mutual fund, or a variable annuity. If he decides on a bank commingled fund, he can choose one sponsored by the Chase Manhattan Bank, the First National City Bank of New York, or the Manufacturers Hanover Trust Company. The creator of the commingled fund, unlike the employer who establishes a pension plan, is in the business of operating such funds. It does not seem inappropriate to impose on him the duty of complying with the provisions of the federal securities laws-particularly when his competitors must do so.

\footnotetext{
act.

${ }^{n}$ See $57(b)$ of the act and item 4 of Exhibit B-1 to the form D-2 which has been issued under the
} 
Despite these considerations, the Commission has not, prior to its H.R. Io position, required the registration of interests in a bank-sponsored commingled fund when the fund is used as an investment medium solely by employee pension plans which meet the qualifications of section for of the Internal Revenue Code. The Commission's position was developed primarily in the context of the use by banks of commingled funds as a way of managing the investment of pension trust assets which were too small to be managed separately. The premise of the Commission's position is that the transactions in which the assets of these pension trusts are invested in the bank commingled funds are exempt under section 4(I) of the Securities' Act from section 5 of the act because they do not involve a public offering. ${ }^{72}$ There would seem to be two ways to support this premise. First, since the trustee of the commingled fund and each pension trust is the same person (the bank), nothing would be gained by requiring disclosure. In those situations where the bank is only one of a number of trustees of the pension trust, the bank's fiduciary duty probably requires it to transmit to its co-trustees all the information concerning the commingled fund which they would need in order to determine whether or not the commingled fund is a suitable investment medium for the pension trust. This argument, however, would seem to collapse if the arrangement made with the bank contemplates that the trust assets (or a certain portion of them) will be invested in a particular commingled fund. In that case, the employer, in effect, makes the investment decision. The second support for the private offering exemption is built on the assumption that the employer who creates the pension trust will be able to fend for himself. ${ }^{73}$ It is assumed that he will set up the pension trust with the aid of a lawyer, accountant and actuary-all of whom presumably are experienced in the area of pension plans and know whether or not the investment medium offered by the particular bank's commingled fund is satisfactory in relation to the investment media provided by other institutions. At a minimum, such employers are thought to be sufficiently sophisticated (and important) to request (and obtain) any information which they think is necessary to an intelligent investment choice. These assumptions may be consonant with the facts in many cases; but they are not in every case.

Although the Commission's extension of the private offering concept to all the transactions in which the assets of employee pension plans are invested in bank commingled funds used solely for that purpose seems logically unsound, its desire not to assume responsibility with respect to such transactions is understandable when viewed in the context of the Commission's early experience with the pension plan area. As pointed out previously, ${ }^{74}$ there was doubt about the power (and more clearly the desirability) of the Commission exercising any jurisdiction with respect to pension or other employee benefit plans which did not involve the purchase by

$7^{2}$ See Memorandum re Securities Act Release No. 4552, reprinted in Fascell Hearing 167-68.

${ }^{78}$ See Securities and Exchange Commission v. Ralston Purina, 346 U.S. Ir9 (1953).

7t See pp. 8II-12 supra. 
employees of securities in the employer company. In addition, when the Securities Act was enacted, bank trusteed pension plans were small in number. The pension trusts of huge corporations such as U.S. Steel Corporation, General Motors Corporation, and American Telephone and Telegraph Company dominated the pension plan world. The assets of these large plans were individually trusteed and were not invested in bank commingled funds. The small, unsophisticated employer rarely seemed to have a trusteed pension plan. Thus, the presence of the type of investor and investment situation for which the protections of the federal securities laws were enacted seemed to be lacking.

The period of rapid growth of pension plans did not occur until late in the r940s. ${ }^{75}$ Bank efforts to share in such growth did not appear to be marked by newspaper or other advertisements which stressed the investment media provided by the banks. These advertisements concentrated on the fiduciary services generally offered by banks. The pension plan business, thus, appeared to have all the earmarks of the type of personal trust business which appeared to be excluded from the operation of the federal securities laws. The absence of any scandals surrounding the operation of the bank commingled funds probably confirmed the Commission's suspicion that its energies and limited resources could be more fruitfully spent elsewhere.

As was the case with respect to voluntary employee contributions to pension plans, the Commission has never articulated its position regarding bank commingled funds in the form of a rule-in this case a rule interpreting section $4(\mathrm{I})$ of the Securities Act. On the other hand, in late 1963 the Commission adopted Rule $156^{76}$ which defines the private offering exemption of section $4(\mathrm{I})$ to include the sale, under certain circumstances, of separate account group annuity contracts by insurance companies to employers. One of the circumstances required to make the exemption effective is that the employer must have at least twenty-five employees at the time the contract is executed. This requirement may be a sufficient indication that the employer will be able to fend for himself when he negotiates such a separate account group annuity contract. However, no such requirement could be written into a rule designed to protect all existing bank commingled funds from the absolute liability imposed by section $12(\mathrm{I})$ of the Securities Act because many such funds have permitted the commingling of assets of pension plans covering fewer than twenty-five employees-indeed, some participating plans apparently cover only

${ }^{75}$ S. REp. No. 1734, 84th Cong., 2d Sess. I2 (1956) sums up the reasons for the great growth of pension plans as follows:

"(I) High corporation taxes during and since World War II, coupled with the allowance of tax deductions for contributions to these programs, thus permitting their establishment at a low net cost.

"(2) Wage stabilization programs during and since World War II and the Korean conflict, which froze wage rates but permitted increased employee compensation in the form of these 'fringe' benefits.

"(3) Court decisions in the years $1948-50$ which made welfare and pension matters a bargainable issue.

"(4) Since 1948 , the drive of labor unions to obtain welfare and pension programs. Labor spokesmen state that another reason for the development of these programs has been the inadequacy of benefits under the governmental programs."

${ }^{70} 17$ C.F.R. $\$ 230.156(1964)$. 
one or two employees. Drawing the rule without reference to some standard which has a reasonable relationship to the ability of the investing employer to fend for himself would appear to be beyond the statutory power of the Commission. Absent a rule there is always the possibility that the bank operating the commingled fund may be subject to absolute liability for having sold a security in violation of the registration requirements of section 5 of the Securities Act. The Commission has no power under the Securities Act to exempt such commingled funds from the registration provisions of the act. ${ }^{77}$

What was it which caused the Commission to refuse to extend its no-action position to the H.R. ro commingled fund? Different Securities Act treatment of H.R. to plans as opposed to employee pension plans cannot be justified on the grounds that in the former case an individual rather than a corporation may create the plan or that in the former employers as well as employees may be covered. The reason for the Commission's position seems related to the fact that for the vast majority of H.R. Io plans it appeared as if the investing employers would be no more able to fend for themselves than the usual purchaser of securities for whose benefit the registration and prospectus requirements of the Securities Act were developed. ${ }^{78}$ Moreover, as pointed out above, it was apparent that a commingled fund could be profitably operated only if a large number of individual H.R. ro accounts were created with the bank. This factor presaged an aggressive merchandising campaign-and the advertisement of the Chase Manhattan Bank seemed to confirm that supposition. Further, the size of the typical H.R. Io account suggested that the personalized service which the banks claimed was a hallmark of their trust business would be omitted or have to be severely curtailed. This thought appeared to be echoed in a speech at the Mid-Winter Trust Conference of the American Bankers Association held in New York in early February 1963. The speaker, G. T. Lumpkin, a Vice President of the Wachovia Bank and Trust Company of Winston-Salem, North Carolina, said:

This [H.R. ro business] is a dramatic change in the nature of trust business. We must meet it with a mind open to possible dramatic change in approach. Rather than the close personal basis on which other types of trust service have been handled, we must look toward an assembly line approach, a semi-automated approach, or even possibly a fully automated approach. Rather than a daily, weekly, or monthly personal contact with a trust customer, we must look to an indirect yearly contact, in many cases through an annual statement mailed to his home or business address. Rather than a trust customer judging us on his intimate knowledge of our service to him to fill his personal needs, he will be judging us strictly on the investment return he receives. Rather than a man-to-man relationship, we must consider a machine-to-man concept of fiduciary service. ${ }^{70}$

\footnotetext{
${ }^{77}$ The Securities Act does not have any provision comparable to the broad exemptive power granted the Commission by $\S 6(\mathrm{c})$ of the Investment Company Act.

${ }^{78}$ One banker estimated that H.R. ro created I9 million new trust prospects. $A$ Fork in the Road, address by G. T. Lumpkin, Jr., 44th Mid-Winter Trust Conference of the American Bankers Ass'n, Feb. 5, 1963 , in Fascell Hearing $1 \mathrm{I}_{4-20}$.
}

${ }^{70} \mathrm{Id}$. at II 4 . 
Whereas employee pension plans had at first grown slowly, with large corporate employers in the forefront and business procedures in many ways identical to those utilized in the banks' traditional trust business, H.R. Io seemed to require rapid growth, the involvement of all segments of the public and many dramatic departures from the trust business in directions normally associated with the securities business.

There are essentially three types of equity investment media in which H.R. Io trusts can be invested: mutual funds, variable annuity contracts, and bank-sponsored commingled funds. ${ }^{80}$ The Commission's position that the interests in each of these media had to be registered under the Securities Act had a different impact on each group of sponsors. For the mutual funds, whose shares were already registered, little change in existing procedures has so far been required. ${ }^{81}$ Typically, a short statement has been included in the prospectus announcing the availability of a plan pursuant to which the mutual fund shares could be used as the investment medium for an H.R. ro trust, stating the name of the custodian bank, and setting forth the charges. $^{82}$

Although the insurance companies had bitterly protested ${ }^{83}$ the Commission's efforts to force their variable annuity funds to comply with the provisions of the Investment Company Act, the same resistance was not made in connection with the registration requirement under the Securities Act for interests in an annuity fund created solely as an investment medium for assets of H.R. Io plans. Indeed, during the time that it was litigating the applicability of the Investment Company Act to its variable annuity fund, the Prudential Insurance Company of America filed a

${ }^{80}$ One variety of the bank sponsored commingled fund is a fund sponsored by an association, such as the American Bar Retirement Association which has been set up for use exclusively by the members of its affliate, the American Bar Association.

${ }^{81}$ Although the offering of interests through a master plan pursuant to which mutual fund shares are used as the investment medium for H.R. Io plans and pursuant to which the shares are held in a custodian account with a designated bank may be considered to involve the offering of a registrable security, the Commission has not required their registration.

${ }^{82}$ The prospectus for Massachusetts Investors Trust, dated March 18, 1963, revised as of May 27, 1963, contains the following statement:

"For those self-employed individuals who wish to purchase shares of the Trust in conjunction with the Self-Employed Individuals Tax Retirement Act of 1962 , there is available through the underwriter a Custody Agreement and Plan. The Custody Agreement provides that the New England Merchants National Bank of Boston, Massachusetts furnishes custodial services as required by such Act, for service fees chargeable to the self-employed individual not to exceed the following amounts: opening the custodial account, $\$ 5.00$; annual maintenance of the account, $\$ 2.00$. Additionally, there will be an annual charge of not to exceed $\$ 6.00$ per employee, plus $\$$ I.00 for each contribution' credited to each employee's account.

"On distribution, termination or retirement there will be a charge to the participant not to exceed the following amounts: for single distribution of cash, shares, annuity policy, government bonds, or return of excess contribution, $\$ 7.00$; for periodic cash distributions, each, $\$ 2.00$.

"For further details, including the right to appoint a successor custodian, see the Custody Agreement and Plan as provided by the underwriter."

${ }^{88}$ Securities and Exchange Commission v. Variable Annuity Life Ins. Co. of America, 359 U.S. 65 (1959); In the Matter of the Prudential Ins. Co. of America, SEC Investment Co. Act Release No. 3620, Jan. 23, 1963, aff'd sub nom., Prudential Ins. Co. of America v. SEC, 326 F.2d 383 (3d Cir. 1964), cert. denied, 32 U.S.L. WeEK 3416 (U.S. June I, 1964); Securities and Exchange Commission v. United Benefit Life Ins. Co., Civ. No. 3096-62, D.D.C. (filed Oct. I, 1962). 
registration statement for its group variable retirement annuity contracts for H.R. Io plans. ${ }^{84}$

The principal objectors to the Commission's position were the banks and the Comptroller of the Currency. ${ }^{85}$ The banks saw a number of difficulties in the Commission's position. If they registered the interests in their commingled funds they would be admitting (a) that the operation of such funds involved the issuance of a security, and (b) that such security was being publicly offered. ${ }^{86}$ Such an admission could be construed as an admission that the banks were violating those provisions of the Glass-Steagall $\mathrm{Act}^{87}$ which attempted to divorce commercial banking from the securities business. ${ }^{88}$ Section 2r of the Glass-Steagall Act ${ }^{80}$ provides that a bank may not be "engaged in the business of issuing, underwriting, selling, or distributing, at wholesale or retail ... stocks . . . or other securities. ..." If the bank commingled funds were considered to be issuing securities, then the bank would arguably be engaged in the business of issuing or at least underwriting such securities. However, the existence of a security for the purpose of the Securities Act does not necessarily result in the existence of a security for Glass-Steagall Act purposes. ${ }^{90}$ A number of examples bear that out. In Securities and Exchange Com-

${ }^{84}$ Not all insurance companies take the position that the Commission may requirc registration of the interests in their variable annuity contracts under the Securities Act. This point is at issue in Securities and Exchange Commission v. United Benefit Life Ins. Co., supra note 83.

${ }^{85}$ The Comptroller of the Currency urged national banks not to register their funds under the Securities Act and offered assistance in court if any of them were sued for failure to register them. Sce statement of James J. Saxon, Comptroller of the Currency, reprinted in Fascell Hearing 162-64. Nevertheless one bank, National Bank of Detroit, has registered its H.R. Io commingled funds. In addition, a number of bank commingled funds which are used as the investment medium for H.R. ro plans sponsored by an association have been registered. These include the American Bar Retirement Association Retirement Plan, the American Medical Association Members Retirement Plan, the National Council of Salesmen's Organizations, Inc. retirement plan, and the Salesmen's Self-Employed Retirement \& Thrift Plans, Inc. retirement plan. The Commission takes the position that the organization sponsoring these plans is the issuer.

${ }^{80}$ During the questioning after his statement before the Legal and Monetary Aftairs Subcommittce of the House Committee on Government Operations [hereinafter referred to as the Fascell Committec], the Comptroller appeared to admit that the operation of an H.R. to program might involvc the issuance of a security and that under certain circumstances such security would have to be registered in compliance with the provisions of the Securities Act.

"MR. MATAN: Mr. Saxon;, if an advertisement did exceed the requirements imposed in regulation 9 [issued by the Office of the Comptroller], I understand it to be your view that there could be a violation of the securities laws perhaps warranting the intervention of the SEC.

MR. SAXON: I think this puts it precisely correct [sic], Mr. Matan. As long as a bank strictly complies with the requirements of this regulation, in our opinion there can be rio reasonable question of the applicability of the SEC laws. If it should step outside in a given case, then the question could well arise, yes, sir." Fascell Hearing 49-50.

${ }^{87}$ Banking Act of 1933 (Glass-Steagall Act), ch. 89, 48 Stat. 162 (codified in scattered sections of 12 U.S.C.).

${ }^{88}$ See Bliss, Eliminating H.R. to Road Blocks, to2 TRUsTs AND Estates 96, 97-98 (1963).

${ }^{80} 48$ Stat. 189 (1933), as amended, $x 2$ U.S.C. $\$ 378$ (1958), as amended, 12 U.S.C. $\$ 378$ (Supp. IV, 1963).

${ }^{00}$ The Glass-Steagall Act became law ig days after the Securities Act. Thus, it may be argued that since an important purpose of the Glass-Steagall Act was to effect a separation of the banking and securities business and since the operation of a commingled fund (at least for bona fide fiduciary trusts) was considered to be a proper banking function, it is reasonable to suppose that such a function cannot involve the issuance of a security within the meaning of either statute. 
mission v. Guild Films Co., ${ }^{91}$ the Second Circuit indicated that a bank acts as an underwriter within the meaning of the Securities Act when it makes a public sale of control stock or restricted stock which had been pledged to it as collateral for a loan. This decision has apparently not been construed to mean that a bank making a sale of stock under such circumstances violates the Glass-Steagall Act. A somewhat similar problem has also arisen in connection with the registration of American depository receipts issued by banks. ${ }^{82}$ In that case it could be argued that the bank is an underwriter of such receipts for the purposes of the Securities Act. In addition, banks have sponsored registered investment companies which sell shares to participating banks. ${ }^{83}$ Finally, the Comptroller of the Currency has specifically authorized the use of bank commingled funds to serve as an investment medium for H.R. Io plans, and it cannot be lightly presumed that he would authorize activity proscribed by the Glass-Steagall Act. ${ }^{94}$

However large the technical hurdles under the Glass-Steagall Act may have loomed in the eyes of the banking community, greater difficulty may have been foreseen in terms of the impact such an admission would have on the broad questions which were being hotly debated concerning the entry of the banks into certain aspects of the securities business. One area involved the

contemplated merchandising of interests in ... collective investment funds as investment media [which], whether in the form of a trust or in the form of a managing agency account, as apparently would be permitted under the proposed revisions of Regulation 9 , would place national banks squarely in the conventional investment company business. ${ }^{95}$

Although the Commission took no position with respect to either the ability under the Glass-Steagall Act or the desirability of the banks to engage in such activities, others did. The Investment Company Institute, for example, suggested that such activities posed "possible dangers to the integrity of the banking system" and questioned the legality of such operations under existing law. ${ }^{86}$ Another area involved an amendment in September 1963 to the Comptroller of the Currency's Investment Securities Regulation which authorized national banks to underwrite revenue bonds of state and local governments. ${ }^{97}$ The Chairman of the Board of Governors of

${ }^{01} 279$ F.2d 485 (2d Cir.), cert. denied sub nom., Santa Monica Bank v. SEC, 364 U.S. 8Ig ( 1960 ).

${ }^{\circ 2} \mathrm{~A}$ brief description of the American depository receipt and the various ways in which it is used is contained in 1 Louis Loss, Securmes Regulation $463-65$ (2d ed. Ig6r).

${ }^{03}$ The Bank Fiduciary Fund was organized by New York state banks. As of April 30, 1963, it had 5 participating banks and assets of not quite $\$ 15$ million. Its adviser is the Manufacturers Hanover Trust Company.

'The Comptroller of the Currency's determination that the operation of such commingled funds is not proscribed by the Glass-Steagall Act is presumably made without reference to the consequences of such activity under the Securities Act.

${ }^{05}$ Letter From William L. Cary to Reese H. Harris, March 7, 1963, in SEC Securities Act Release No. 4589 , March 11, 1963.

${ }^{00}$ Memorandum on Behalf of Investment Company Institute in Opposition to Proposal to Exempt Collective Investment Funds Operated by Banks From the Federal Securities Laws, pp. 24-40. This memorandum was submitted in opposition to a proposed Bank Collective Investment Fund Act of I963, S. 2223. H.R. 8499, H.R. 9410, 88th Cong., Ist Sess. (1963). For a discussion of these bills see pp. $83 \mathrm{I}-33$ infra.

oт 28 Fed. Reg. 9916 (1963). 
the Federal Reserve System and the Investment Bankers Association of America protested that since such bonds were not "general obligations" of a state or political subdivision, they fell outside the permissible area of bank underwriting activity. ${ }^{98}$

The banks may also have been afraid that if they admitted that the operation of an H.R. Io commingled fund involved the public offering of a security that it would be difficult to deny that the operation of commingled funds used to fund the assets of employee pension plans also involved the public offering of a security ${ }^{90}$ However, it may be that the banks could have seized on the Commission direction to register their H.R. xo commingled funds as a device for insulating these funds and their employee pension commingled funds from the absolute liability which is imposed by section I2(I) on the sale of unregistered securities. The banks might have invested the assets of the H.R. Io trusts in the fund used to pool employee pension trust assets and then registered the fund under protest-thus preserving the arguments with respect to the non-applicability of the Securities Act. ${ }^{100}$ At the same time, the one-year statute of limitations with respect to section I2(I) liability would be running on all interests in employee pension plan commingled funds sold prior to registration.

Perhaps the major objection which the banks raised to the Commission's assertion of jurisdiction over the operation of their commingled funds was an unwillingness to be subjected to what they termed the "visitorial power" of still another federal agency. This feeling is clearly expressed in the testimony of the Comptroller of the Currency during hearings before a Subcommittee of the Senate Committee on Banking and Currency on the Commission's proposed amendments to the Securitics Exchange Act which would make certain provisions of that act applicable to bank securities. The Comptroller was asked whether, if Congress decided to apply these provisions to banks, he would consider it preferable to do so by amendment of the Banking Act rather than the Securities Exchange Act. The Comptroller replied:

Yes, sir, by amendment to the appropriate banking acts and not to the SEC act. I would hate to see any tie-in with the SEC statutes as such or policies or regulations, whether by amendment to that act, by any delegation from that act, vesting from that act, or otherwise. ${ }^{101}$

The banks felt that they were "closely, intimately, intensively regulated institutions" and that any further regulation would be both superfluous and burdensome. ${ }^{102}$

${ }^{88}$ The Wall Street Journal, Sept. 25, I963, p. 59, col. 3, p. 67, cols. 3-5; N.Y. Times, Aug. 26, 1963, p. 37 , cols. I-2, p. 38 , col. 4 . York).

${ }^{90}$ See Fascell Hearing 86 (testimony of Charles W. Buek, President, United States Trust Co., New

${ }_{100}$ There would be no insulation from liability if such interests were sold as a result of false or misleading selling practices. Securities Act $\$ \mp 7(a)$; Securities Exchange Act $\$$ IO(b). The same liability applies if the Commission's position concerning the existence of a private offering exemption is correct. Such an exemption applies only to the provisions of $\$ 5$ of the Securities Act. In addition, registration of this fund would not eliminate any Securities Act problems which might worry the banks with respect to the operation of their common trust funds.

${ }^{101}$ Hearings on S. 1642 Before a Stbcommittee of the Senate Committee on Banking Currency, 88th Cong., Ist Sess. I8I (1963).

${ }^{102}$ Fascell Hearing 44. 
The exemption of bank securities from the definition of security in section $3(a)(2)$ of the Securities Act can be pointed to as demonstrating a congressional determination that adequate supervision over the issuance of bank securities was exercised by the appropriate banking authorities and that, therefore, the protections of the Securities Act did not have to be extended to investors in such securities. The Comptroller argued that supervision over the trust activities of banks was more rigorous than any other bank activity. He said:

There is no more carefully devised or restrictive set of laws or regulations in any field of banking, in my opinion, than that appertaining to the law of trusts, because of the special and traditional significance attached to the fiduciary relationship and existing for centuries, both in the common law and the statute law of this country. ${ }^{103}$

Consequently, if any securities were issued by such trusts they, at least as much as any bank issued security, should be exempt from the definition of securities under the Securities Act. ${ }^{104}$

A strikingly similar argument occurred during the Senate hearings on the Commission's proposal to extend to investors in over-the-counter securities (including bank securities) the protections of sections 12, I3, I4 and I6 of the Securities Exchange Act. The proposal provided that the powers, functions and duties of the Commission with respect to bank securities would be delegated to the appropriate federal bank regulatory authority upon its request. ${ }^{105}$ The Comptroller argued that the proposed extension of these investor protections to holders of bank securities was unnecessary. He pointed to the pervasive quality of bank regulation:

While it is obvious that we consider disclosure of great importance, we regard direct supervision of banks of greater value. The combination of these two forms of public ${ }^{103}$ Ibid.

101 The Comptroller's position does not reflect the view of all bank regulators. For example, Jarnes L. Robertson, a governor of the Federal Reserve Board, said at the Senate hearing on the confirmation of his appointment that the Commission should exercise jurisdiction over H.R. to commingled funds:

"SENATOR DOMINICK. We are having problems and have been for some time on the question of whether the Comptroller of the Currency or the Securities and Exchange Commission has jurisdiction over common trust funds and so-called Smathers-Keogh [H.R. IO] investments. ...

"MR. ROBERTSON. Under my proposal the [federal banking] Commission would have all the regulatory powers and functions that are now vested in any one of these three Federal banking agencies. The question of where the power lies as between the Securities and and Exchange Commission and the Comptroller of the Currency would not be affected. My own feeling is the Securities and Exchange Commission has greater competency in the field than does any bank supervisory agency and therefore, I'd leave it in that Commission.

"SENATOR DOMINICK. So at the present minute you believe the commercial banks, so far as common trusts and Smathers-Keogh funds are concerned, should be under the jurisdiction of the Securities and Exchange Commission?

"MR. ROBERTSON. I do."

Hearing on the Nominations of Hugh F. Owens To Be a Member of the Securities and Exchange Commission and James L. Robertson To Be a Member of the Federal Reserve Board, Before the Senate Committee on Banking and Currency, 88th Cong., 2d Sess. 26-27 (1964).

${ }^{105}$ S. 1642 , 88th Cong., Ist Sess. $\$ 3(e)(1963)$ (as introduced). The Senate Committee, however, with the agreement of the Commission, amended the bill to provide that these powers and duties shall be vested in the respective bank regulatory agencies. S. REP. No. 379, 88th Cong., Ist Sess. 3I-36 (1963). 
control gives the bank investor much greater protection than any other investor. No one should denigrate the direct supervision of banks as an effective means of public control. The continuous internal supervision, regulation, and examination of banks by federal and state bank supervisory agencies provides a protection to investors in banks which is far greater than that afforded by disclosure alone. For example, the National Bank Act requires that a complete examination at least three times in every 2-year period of the books and records of each national bank must be made by a bank examiner employed by the Comptroller of the Currency. Each of these examinations involves a detailed analysis and valuation of the assets and liabilities of the institution. This supervision provides protection for depositors and shareholders alike which is not available to investors in any other type of corporation. ${ }^{106}$

The Commission argued that the thrust of bank regulations was not the same as that of the federal securities laws-the former, claimed the Chairman of the Commission, focused on the protection of the depositors, whereas the latter focused on the protection of investors:

Accordingly, the only remaining issue is whether present practices of banks are such that the purposes of S. $x_{42}$ have already been satisfied. The great objectives of banking regulation are controls over the flow of credit in the monetary system, the maintenance of an effective banking structure, and the protection of depositors. These objectives neither utilize the same tools nor achieve the same ends as investor protection. The purpose of disclosure is to place the investor in a position to make an informed judgment on the merits of a security, and to provide a basis for comparing that security with others issued by companies in the same or different industries. Essentially this purpose is achieved through the furnishing of financial information which provides a uniform pattern of reporting based on understood and generally accepted accounting practices. To say that bank regulation renders this disclosure philosophy unnecessary is to say that bank regulation is an effective substitute for the free exercise of an investor's judgment. Controls which protect against embezzlement and which assure adequate reserves serve important objectives, but not the objective of informed investment. To hold otherwise would be to imply that, because of such regulation, bank securities are, without more, worthy investments. ${ }^{10 t}$

The argument was eventually resolved by the Senate in favor of the Commission's position. ${ }^{108}$ However, the proposed amendments to the Securities Exchange Act do not purport to disturb the exempt status of bank securities under the Securities Act and it is, of course, the provisions of that act which govern the need for banks

${ }^{108}$ Hearings on S. 1642 Before a Subcommittee of the Senate Committee on Banking and Currency, 88th Cong.. Ist Sess. $175-76$ (1963).

${ }^{107}$ Id. at $54-55$.

${ }^{108}$ S. 1642 , supra note 105 , was passed by the Senate. At the time this article was written hearings had been held by a Subcommittee of the House Committec on Interstate and Foreign Commerce on the Commission's proposals. The Subcommittec reported H.R. 6793, 88th Cong., 2d Sess. (1964), the House version of S. I 642, to the full Committee on March 26, 1964. The House Committee reported the bill on May 19, r964. H.R. REp. No. I4I8, 88th Cong., 2d Sess. (1964). The Senate's action on the Commission's proposals should be contrasted with the recommendation of the Fascell Committee to the Interstate and Foreign Commerce Committec to consider legislation which would specifically excmpt H.R. xo commingled funds from the federal securities laws and provide for such investor protections as may be deemed necessary. H.R. Rep. No. 429, 88th Cong., Ist Sess. 4 (1963). 
to register the interests in the commingled funds used as H.R. ro investment media. The technical legal argument for the banks is simple. If a security is issued in connection with the creation of its commingled funds then the bank which created the fund must be the issuer of that security. Since the security is one issued by a bank, it is exempt from the provisions of the Securities Act by virtue of section 3 (a) (2) of that act. ${ }^{109}$ One answer to that argument is that section 3(a)(2) only exempts securities issued by a bank qua bank-that is, where the securities issued represent an interest in or an obligation of a bank. The section 3(a) (2) exemption is not available when a bank issues securities in its capacity as a trustee. The other answer is that, as in the American depository receipt situation, it is the fund or trust -and not the bank-which is the issuer. ${ }^{110}$ That answer immediately runs into section 2(4) of the Securities Act which provides that

with respect to certificates of interest or shares in an unincorporated investment trust not having a board of directors ... the term "issuer" means the person or persons performing the acts and assuming the duties of depositor or manager pursuant to the provisions of the trust ... under which such securities are issued ....

Since the bank performs the duties of manager or depositor in connection with the commingled fund it would appear that it is the issuer of the securities and that the section 3(a) (2) exemption problem is again raised. The answer to this contention may lie in the legislative history of section $2(4)$ which indicates that in certain situations in which securities were deposited pursuant to a trust or similar arrangement, the person holding the securities did not have the information relative to the securities which was required to be included in the registration statement. ${ }^{111}$ The person who had the necessary information was the depositor or manager and, accordingly, the responsibilities of an issuer were imposed on him rather than on the trust or trustee which is the "actual issuer."112 One example which may be cited

${ }^{100}$ Section $3(a)(2)$ of the Securities Act exempts from its operations: “. . . any security issued or guaranteed by any national bank, or by any banking institution organized under the laws of any State or Territory or the District of Columbia, the business of which is substantially confined to banking and is supervised by the State or Territorial banking commission or similar official . . . "

${ }^{120} \mathrm{~A}$ statement of the Commission's position in the analogous case of the American depository receipt is contained in 22 SEC ANN. REP. 43 (1956). Cf. Supplemental Statement of Hon. Ganson Purcell of the Securities and Exchange Commission, in 1941 Hearings 1018.

Although the language in the Commission's Prudential opinion; supra note 83 at ro \& n.22, is not clear, the Commission staff appears to be taking the position that for Securities Act purposes the Prudential Insurance Compay is the issuer of the interests in its variable annuity fund. The company filed the registration statement for its group variable annuity accounts on the assumption that it was the issuer. File No. 2-21905. There is no exemption comparable to that contained in $\S 3$ (a) (2) for securities issued by insurance companies and, thus, even if the variable annuity fund were the issuer for Securities Act purposes, the Prudential Insurance Company would probably have an issuer's liability as a controlling person of the fund under $\$ I_{5}$ of the Securities Act. If a bank cannot be held to an issuer's liability with respect to the issuance of interests in its commingled fund solely because of the exemption in $\$ 3(2)(2)$, it would seem that the bank should not be held to an issuer's liability as a controlling person of the fund.

${ }_{112}$ H.R. ReP. No. 85, 73d Cong., Ist Sess. I2 (1933). It may also be argued that $\$ 2$ (4) addresses itself solely to the question of who has the issuer's liability and does not deal at all with the question of whether a registration statement is required.

112 Ibid. 
involves the American depository receipt instrument. That instrument originally developed in a situation where an American investment banker was anxious to facilitate the distribution of the shares of a foreign company. A bank was the depository of the securities and issued receipts for them. The investment banking firm retained the right to exercise managerial control over the deposit. A similarsituation occurs in connection with unit trusts created for the purpose of accumulating investment company shares. In both cases, the depositor or manager initiates the distribution of the securities and has the information which must be included in any registration statement. It does not seem fair to place the duty and liability of an issuer on the depository who plays essentially a passive role in the transaction. In the H.R. Io situation, the trustee of the commingled fund is not a passive participant and has all the information needed to comply with the disclosure provisions of the Securities Act. Consequently, this is a situation where the language of section 2(4) must be interpreted in the light of the introductory clause of section 2-"unless the context otherwise requires."

Although this interpretation makes the trust the issuer and avoids any section 3(a) (2) problem, it probably results in relieving the bank of an issuer's liability. The second "except" clause of section 2(4) states that the trustee is not individually liable as an issuer with respect to securities issued by a trust of which it is the trustee. It is the trust which has the issuer's liability. ${ }^{113}$ However, this does not relieve the bank entirely from responsibility for the content of the registration statement since it is probably the underwriter of the securities issued. ${ }^{114}$

Although the question of whether or not the Commission should have jurisdiction with respect to the activities of bank commingled funds was hotly contested, there was no controversy with respect to the need for disclosure. The Comptroller of the Currency pointed out that his office has "given great emphasis to disclosure."115 He pointed with evident pride to the expanded disclosure requirements contained in his new Regulation 9.116 Section 9.x8(b)(x) of the Regulation provides that

${ }^{113}$ See H.R. REP. No. 1838 , 73d Cong., 2d Sess. 39 (1934). Query, however, whether the bank has a controlling person's liability under section 15 of the Securities Act.

114 Some banks have apparently decided to wait out the resolution of the conflict between the Commission and the Comptroller of the Currency by confining the offer of participations in H,R. 10 commingled funds to residents of the state in which they are incorporated and are doing business. They would, therefore, be exempt from the registration requirements of the Securities Act by virtue of the provisions of $\S_{3}(\mathrm{a})(\mathrm{II})$. Any bank offering interests in an H.R. ro commingled fund in reliance on this exemption would have to be sure that no interest in the fund is, at any time, offered or sold to any nonresident of the state. See SEC Securities Act Release No. 4434, Dec. 6, 196r. Since employec participants in the H.R. Io plan are usually offered an opportunity to make voluntary contributions to the plan which will be invested in the commingled fund, it seems that the bank must make sure that not only the participating employer but also all his employees are residents of the state.

${ }^{115}$ Fascell Hearing 44. However, he insisted that disclosure was less important than the kind of regulation to which banks were subject. He said:

"Yet this [disclosure] can never be a substitute, in any sense of the term, in my opinion, for the intensive, continuing intimate regulation of the business as occurs in banking." Ibid.

${ }^{116}$ It should be noted that these requirements of Regulation 9 apply only to national banks and not to state banks such as the Chase Manhattan Bank, insofar as commingled funds used only for qualified plans (including H.R. Io plans) are concerned. For, although state banks must in general comply with 
each commingled fund must be established and maintained in accordance with a written plan and that this plan must be flled with the Office of the Comptroller of the Currency. This plan must, at a minimum, explain how the fund is to be operated; the investment powers given to the bank with respect to the fund; the allocation of income, profits and losses between principal and income accounts; the terms and conditions governing the admission or withdrawal of participants in the fund; the auditing of accounts of the bank with respect to the fund; the basis, method and the minimum frequency for valuing the assets in the fund, and the basis upon which the fund can be terminated. ${ }^{117}$ Section 9.18(b) (5) provides that each fund must annually prepare a financial report which also must be filed with the Office of the Comptroller of Currency. This report must contain a list of the investments in the fund, showing the current market value of each investment; a statement showing purchases, sales and any other investment changes; a statement of income and disbursements; and notations as to any investment in default for the period covered by the report. Any person who requests a copy of the plan is entitled to receive it. Similarly, any person who requests a copy of the annual report is entitled to receive it. In addition, a copy of the annual report must be furnished, or notice of its availability must be sent to each person to whom a periodic accounting would ordinarily be rendered.

Expanded disclosure requirements were also a feature of the proposed Bank Collective Investment Fund Act of $1963^{118}$ which the American Bankers Association supported as a method for solving the dispute between the Office of the Comptroller and the Securities and Exchange Commission. This proposed act sought to exempt from the application of the federal securities laws interests in bank commingled funds (including interests in funds used as an investment medium by pension and profit-sharing plans which are exempt from income tax). In return for such exemption, the Bank Collective Investment Fund Act would have imposed certain disclosure requirements upon such commingled funds. Section $6(\mathrm{~b})$ of the act specifically authorized the Comptroller of the Currency to make such rules and regulations as he deemed appropriate "for the disclosure of relevant information to persons having interests in accounts presently or prospectively participating in such collective investment funds."118 The act went on to impose certain minimum disclosure requirements. Sections 6 (c) and (d) of the act, concerning the plan describing the fund,

Regulation 9 in the operation of their common trust funds in order to obtain the favorable tax treatment accorded such funds by $\$ 584$ of the Internal Revenue Code, commingled funds used only for qualified pension plans can qualify for tax exemption under $\$ \S 40 \mathrm{I}(\mathrm{a})$ and $50 \mathrm{r}(\mathrm{a})$ of the Code and are therefore not dependent on $\$ 584$. Rev. Rul. 56-267, I956-r CuM. Bull. 206.

${ }_{117}$ There is also a catch-all closing phrase requiring the plan to contain provisions relating to "such other matters as may be found necessary to define clearly the rights of participants in the fund."

${ }^{118}$ S. 2223 , H.R. 8499, 88th Cong., Ist Sess. (1963). Congressman Fascell introduced an identical bill in December r963. H.R. 9410, 88th Cong., Ist Sess. (1963). Hearings before the Subcommittee on Commerce and Finance of the House Committee on Interstate and Foreign Commerce on H.R. 8499 and H.R. 9410 were scheduled to begin on June 9,1964 .

110 The Comptroller is also given broad exemptive powers under $\S 6(i)$ of the act. 
are roughly equivalent to section $9.88(\mathrm{~b})(\mathrm{I})$ of the Comptroller's Regulation 9. Section 6(e) of the act, which refers to the annual financial report which the commingled fund is required to issue, is more detailed than the comparable provision in section 9.18(b) (5) of Regulation 9. It requires a detailed listing of all assets and liabilities of the fund, showing both the cost and market value of the assets and concentration by major fields. In addition, it requires a statement of increases or decreases in gross asset valuation since the last prior report, a statement of earnings, a statement of realized gains and losses, and a statement of investments purchased, sold or redeemed since the last prior report. Section $6(f)$ of the act requires that at or prior to the time of the first participation of any account in the collective investment fund, a copy of the plan as currently in effect (or a summary of it) and a copy of the latest financial report be furnished, with respect to each such participating account, to all non-bank co-fiduciaries of each such participating account and to each person who has the right to be consulted about investments or to amend or revoke the terms of the instrument creating the account. ${ }^{120}$ Section 6(e) of the act requires that thereafter these same persons must either receive copies of annual reports and of any amendments to the plan or be given notice that such documents will be furnished to them on request without charge. ${ }^{121}$

The Commission objected to this compromise bill. In a letter to Senator Willis Robertson, the Chairman of the Senate Banking and Currency Committee, dated November $27,1963,{ }^{122}$ the Chairman of the SEC stated that the standards of disclosure in the Bank Collective Investment Fund Act were "meager and inadequate" when compared to those imposed by the Securities Act. He pointed out that, under the Bank Collective Investment Fund Act, banks may solicit investment in their funds by using sales literature unaccompanied or preceded by anything in the nature of a prospectus. ${ }^{123}$ The prospectus substitute contemplated by the act could consist of a copy of the plan creating the fund (which might be a complex legal document) and a copy of a financial report for the latest year. Such a requirement did not, he wrote, insure that the investor would be told what his rights in the fund were in an intelligible form. He went on to state that disclosure of certain fundamental matters, such as the persons who perform the advisory functions for the fund (which, he pointed out, did not need to be the bank) or the investment performance of the fund, were not required. He also commented on the difference between making

${ }^{120}$ As drafted, $\S 6(f)$ of the Bank Collective Investment Fund Act would not require furnishing of the plan and latest financial report to employees who make voluntary contributions to their H.R, ro trust, since such employees normally do not have the right to amend or revoke the terms of such trust.

${ }^{12 x}$ The comment made in note 120 supra applies equally here.

122 rog Conc. Rec. 23997 (daily ed. Dec. 19, 1963).

${ }^{198}$ Under present $\$ 9.18$ (b)(5)(iv) of Regulation 9, it appears that the bank cannot use any sales literature describing the fund. Publicity is confined to distribution of the annual report and the publication of a summary of the report in a newspaper of general circulation where the principal office of the bank is located. The availability of the report may be given publicity in connection with the promotion of the fiduciary services of the bank. As pointed out at note 1 I 6 supra, however, these restrictions do not necessarily apply to state banks in connection with their commingled pension fund activity. 
annual financial reports available and requiring them to be mailed to the participants. Finally, he asserted that the Bank Collective Investment Fund Act deprived investors of the kind of civil remedies provided by the federal securities laws to redress failure to make the required disclosures. ${ }^{24}$

The issue appeared to be how much disclosure is enough. The question of who should have the power to ensure that proper disclosure would be made seemed to be a secondary consideration-at least in the mind of the Chairman of the Securities and Exchange Commission. When asked whether he would be satisfied if the federal securities laws were applied to bank commingled funds with administrative responsibility, however, being vested solely in the Comptroller of the Currency, he replied:

I cannot sit here and commit my Commission to a policy position on that. But I would say it is a different question, and I am quite free to recognize it.

In other words, we are not fighting for jurisdiction in that sense.

... I don't feel I spend my life here worrying about the loss of a small facet of one's activities, or prospective loss of it. If we knew it were going to be fully handled by another agency, it would be a different question. ${ }^{125}$

On the other hand, the Chairman pointed out in the letter to Senator Robertson that "governmental efficiency and uniformity of treatment would be best served by having the federal securities laws administered by one agency"-the Commission. ${ }^{126}$

${ }^{126}$ It may be possible to imply a civil remedy from $\$ 9$ of the Bank Collective Investment Fund Act which makes it a crime, punishable by a fine not to exceed $\$ 25,000$, for any bank to willfully violate any provision of the act, or to willfully, in a plan or report filed under the act, make any untrue statement of a material fact or omit to state any material fact necessary in order to prevent the statements made from being materially misleading.

The objections to the Bank Collective Investment Fund Act went beyond the inadequacies of the disclosure provisions. Chairman Cary's letter indicates that the Commission's basic quarrel was with the provision of a separate standard of regulation for collective investment funds maintained by banks. He wrote:

"This technique underscores the fundamental criticism which the Commission has of the bill. The bill says, in effect, that even though a bank merchandises interests in one of its collective investment funds to the public, it has not entered the securities business. It is the Commission's position that the bank has, at that point, entered the securities business, and that the same rules for investor protection should, at that point, be applicable to the bank as are applicable to other persons in the securities business. The emphasis of the Congress and the Commission over the last 30 years has been on the development of uniform rules for the protection of all investors. No purpose seems to be served by enacting special legislation for the protection of investors whose contact with the securities business is through banks merely because the banks have decided that the securities business is a profitable one in which to engage." Iog Cong. Rec. 23998 (daily ed. Dec. I9, 1963).

The letter went on to state that the bill appeared to be a technique for avoiding adequate congressional consideration of the important policy questions raised by the banks' entry into the securities business.

"One reason that the bill has been drafted to deny that banks have entered the securities business in certain of their commingled fund activity apparently is to avoid any problems which might be raised under those portions of the Glass-Steagall Act which prohibit commercial banks from engaging in such business. To the extent that such problems exist, Congress will no doubt .wish to deal with them directly. They should not be disposed of by a drafting technique, particularly when such technique would entail the loss of important safeguards for investors." Ibid.

${ }^{125}$ Fascell Hearing 16.

${ }^{130}$ As pointed out in note 105 stpra, S. 1642 vested administrative responsibility for certain provisions 


\section{A. The Commingled Fund and the Investment Company Act}

The commingled fund, no less than the individual pension trust, fits the definition of investment company contained in section 3 of the Investment Company Act. However, although there may be cogent reasons to exempt an employer's individual pension plan from the provisions of that act, none of these reasons support an exemption for the commingled fund in which such plans might invest. If Scudder, Stevens and Clark, for example, had decided not to permit H.R. xo plans to fund their investments in its already established mutual funds, but had instead created a new mutual fund solely for the purpose of funding such plans, it is hard to imagine in what way the new fund would be operated differently than its already established funds (which must comply with the Investment Company Act).

Section 3(c) (13) of the Investment Company Act which excepts from the definition of investment company employees' pension trusts meeting the conditions of section 165 (now section 40r) of the Internal Revenue Code has, however, always been interpreted to extend to the commingled funds in which such trusts were invested if such commingled funds themselves were ruled to qualify for tax exemption under section 40I. ${ }^{127}$ The Internal Revenue Service has ruled that such qualification is met by a U.S. commingled fund if it is adopted as part of the plans under which the participating trusts are created, and if the instrument governing the commingled fund expressly limits participation to trusts which meet the requirements of section 4or, prohibits property in the commingled fund from being diverted to any purpose other than the exclusive use of the participants in the fund, and prohibits any interest in the commingled fund from being assignable. ${ }^{128}$ As was pointed

of the Securities Exchange Act in the bank regulatory agencies. However, that cession of authority would not seem to be a precedent for granting these agencies the power to administer the federal sccuritics laws as they apply to bank-sponsored commingled funds. In the first case, the provisions of the Securities Exchange Act in question apply to the bank itself-and the bank regulatory authorities have an expertise with respect to the operation of the bank business. On the other hand, in the case of bank-sponsored commingled funds, the federal securities laws would apply to the fund rather than to the bank-and it is the Commission which has the expertise with respect to the operation of pools of sccuritics.

${ }_{127}$ The special treatment under the Investment Company Act implied for employecs' securities companies by $\S 6(\mathrm{~b})$ of the act does not apply to bank commingled funds since such funds do not fit the definition of an employees' securities company contained in $\$ 2(a)$ (13) of the act.

${ }^{128}$ Rev. Rul. 56-267, 1956-I Cum. Bulz. 206. There may be an additional exemption with respect to bank commingled funds under $\S_{3}(c)(3)$ of the Investment Company Act. This section exempts from the definition of investment company "any common trust fund or similar fund maintained by a bank exclusively for the collective investment and reinvestment of monies contributed thereto by the bank in its capacity . . . as a trustee." It may be argued that the contributions to the commingled fund were made by the bank as the trustee of the individual participating trusts. The Commission accepts this argument if the individual participating trusts were created for bona fide fiduciary purposes, as that term was defined by the Federal Reserve Board in the 25 years during which it supervised the opeartion and administration of common trust funds. When interests in the commingled fund are merchandised to the public as investment media, the Commission (as did the Federal Reserve Board) has taken the position that the participating trusts are not created for bona fide fiduciary purposes. In the case of commingled funds for H.R. Io plans, the Commission apparently believes that the investment appeal of the commingled fund is central to the creation of the relationship between the bank and its H.R. Io customer: The creation of the H.R. ro trust is incidental to the relationship. Put another way, the Commission seems to assume that the employer is, in effect, offered a participation in the com- 
out above the legislative history of section 3 (c) (13) is not very helpful in determining why this exemption was put into the Investment Company Act. Perhaps the application of the exemption to the commingled fund reflects a judgment about the importance of encouraging the creation of pension plans (including small ones whose assets must be commingled with the assets of other pension plans to achieve efficient management and adequate diversification) weighted against the cost and perhaps the efficacy of the investor protections provided by the Investment Company Act. Such a judgment may have been easier to make at a time when it was assumed that the participating employers in such commingled funds were persons able to fend for themselves. ${ }^{129}$ Some weight may also have been given to the fact that such commingled funds were normally sponsored by banks which themselves were already subject to a certain degree of oversight. ${ }^{130}$ In addition, extending the Investment Company Act to such funds raised the difficult question of who should receive the right to vote. If the trustee of the participating trusts had the power to vote, the bank would normally control the fund. ${ }^{131}$ Another solution would have been to give the vote to the employer. However, that would give no voice to those employees who had made contributions to the employee pension trust or who had acquired vested rights in the trust.

Since it seemed clear that the Treasury would rule that H.R. ro commingled funds qualified for tax exemption under section 4 or of the Internal Revenue Code, the Commission undoubtedly felt a strong pressure to extend to such funds the same exemption it had extended to the other commingled funds. The situations could have been distinguished. The employer-participants in this fund were clearly not able to fend for themselves. Moreover, the problem of who should have the vote

mingled fund and that the creation of the employer trust is the technical device by which such investment is permitted.

${ }^{120}$ Rule $3 c-3$ of the General Rules and Regulations under the Investment Company Act, I7 C.F.R. $\$ 270.3 \mathrm{C}-3$, exempts certain group deposit administration contracts and the segregated accounts in which they are funded from the provisions of the Investment Company Act if the contracts meet certain conditions. Recently the Commission proposed an extension of this exemption to group variable annuity contracts. SEC Investment Company Act Release No. 3957, April $x_{3}, 1964$. One of the conditions which the group deposit administration contracts and group variable annuity contracts must meet to qualify for the exemption is that, at the time the contract is executed, it must cover at least 25 employees. Sec p. 821 and note 31 supra for a discussion of Rule 156 which provides a similar exemption from the Securities Act. This condition may provide some assurance that the employer will be able to exercise a suficient degree of supervision over the activities of the insurance company sponsor of the commingled fund so that he may not be in need of the protections afforded by the Investment Company Act. However, the Commission has never applied this reasoning to investment companies in those situations where cach shareholder was required to be a substantial investor. The Exchange Fund of Boston, for example, required each shareholder to make an initial investment of at least $\$ 25,000$, but this did not affect its status under the Securities Act or the Investment Company Act.

130 The extent to which bank regulation differs from the regulation contemplated by the Investment Company Act is discussed in the Fascell Hearing II-I3, 44-46.

${ }^{101}$ Even if the bank had majority control, some purpose might be served by making the commingled fund account to the minority of non-bank co-fiduciarits. Major dissatisfaction on the part of such cofiduciaries would probably cause the fund to change the policics which caused such dissatisfaction. However, the same purpose would probably be served by enforcing the disclosure provisions of the federal securities laws. 
would be simplified. Since the interests of all employee and employer participants in H.R. Io trusts vest immediately, it would make sense to allocate voting rights in accordance with such vested rights. ${ }^{132}$ The statutory basis for the distinction might have been based on the restriction of the section $3(\mathrm{c})(\mathrm{r} 3)$ exemption to "employee" pension trusts. H.R. Io covers self-employed persons' pension trusts. The drafting technique which the Internal Revenue Code adopted to permit H.R. ro trusts to qualify under section $40 \mathrm{I}$ was to state that a self-employed person who met certain qualifications would be called an employee for the purpose of applying section 4or. However, since the purposes of the Internal Revenue Code and Investment Company Act are very different, there is no need to give the same interpretation to the term employee as used in the Investment Company Act as is given to it in the Internal Revenue Code. This is particularly true where, as in this case, the shift from employee pension trusts to self-employed persons' pension trusts underscores the greater need for investor protection. Some support for this approach may, perhaps, be found in the use of the words "as amended" in section 3 (c) (13). They were put into the section the last time an amendment was made in section 40I which substantially affected the qualifications which a trust had to meet in order to qualify under section $40 .^{133}$ The words were added so that the change made would be read into section 3 (c) (13). ${ }^{134}$ The language used is much narrower than the broad-"as heretofore or hereafter amended"--which is used in section 2(a) (42) of the Investment Company Act. ${ }^{135}$ However, the Commission considered that the policy which is reflected in section 3 (c) (13) of the act indicated that the exemption clearly should extend to H.R. Io plans at the level of the individual employer fund; and it has not attempted under this act to apply different treatment at the level of the commingled fund.

As a consequence of the extension of the section $3(\mathrm{c})\left(\mathrm{r}_{3}\right)$ exemption to H.R .xo commingled funds, considerable pressure by competitors of the banks (banks were the primary beneficiaries of this construction) for a compensating exemption could be expected. The pressure came almost immediately. The Prudential Insurance Company of America desired to participate in what it conceived to be the lucrative market for H.R. Io business. However, its commingled fund (a variable annuity account) did not quite fit the language in the section $3(\mathrm{c})\left(\mathrm{I}_{3}\right)$ exemption because

${ }^{132}$ In those pension trusts where the rights of the participants do not vest immediately, the problem of who should vote on behalf of the holders of contingent interests is presented. One possible solution would be to distribute that vote among the holders of vested interests. Other solutions would be to permit the employer to exercise that vote or to let the holders of the contingent interests themselves exercise the vote.

${ }^{133}$ The Revenue Act of 1942, ch. 619, 56 Stat. 798 (1942), added provisions that were intended to prevent employers from establishing plans which discriminate in favor of top management.

${ }^{134}$ See S. Rep. No. I631, 77th Cong., 2d Sess. I42 (1942).

${ }^{135}$ It is interesting to note that the present policy of the House Legislative Counsel is to avoid use of the phrase "as heretofore or hereafter amended" in statutes when the intention is in fact to refer to a statute as "heretofore or hereafter amended." This was made express in the House report on the Commission's pending legislative program. See H.R. REP. No. I4I8, 88th Cong., 2d Sess. 22 (1964). 
it was not a trust. ${ }^{138}$ The argument advanced for granting the exemption rests on the theory that Prudential had fiduciary duties very similar to those of the trustees of a commingled fund; that applying the Investment Company Act to Prudential and not to its leading institutional competitor would put it at a severe (and congressionally unintended) economic disadvantage; and, finally, that insurance companies, no less than banks, were heavily regulated. ${ }^{137}$

\section{ConcLusion}

Any consideration of employee or H.R. Io benefit plans must make a sharp distinction between two factual levels. The first is the level of the individual plan and the relation to it of the employee participants. The second is the level of the investment medium which is used to fund the individual plan and the relation to that medium of the employer who sets up the plan and chooses the investment medium.

At the level of the individual plan, the Commission has under the Securities Act followed a hands-off policy with respect to all plans except those involving the sale to employees of securities in the employer company. The Commission's policy developed during a period when the need for legislation designed to protect the interests of plan participants had not been clearly established; and it was guided by the fact that the Securities Act had neither been intended nor designed for widespread application to protect the interests of participants in all kinds of welfare and pension plans. The evolution of the Commission's hands-off policy is thus understandable. Its continuation is appropriate. For, although there may once have been some reason for applying the protections of the Securities Act at the individual plan level to plans not involving the sale of employer securities, this has no longer been the case since the enactment by Congress of the Federal Welfare and Pension Plans Disclosure Act. The Federal Welfare and Pension Plans Disclosure Act is specifically designed to provide at the individual plan level the protections which Congress has decided are appropriate for participants in the many kinds of welfare and pension plans which eixst. Thus, for all plans except those involving the sale of employer securities, the Federal Welfare and Pension Plan Disclosure Act rather than the Securities Act should be looked to as the embodiment of congressional policy. The Commission's hands-off policy under the Securities Act harmonizes with this result. However, as discussed above, the Commission's hands-off policy has not been incorporated in interpretative or exemptive rules; indeed, the Commission's power to adopt an exemptive rule is limited by the $\$ 300,000$ ceiling which is presently contained in section $3(b)$ of the act. The consequence is that at least some employee and H.R. Io plans are continuously being subjected at the individual plan level to possible

${ }^{108}$ When Prudential filed its registration statement under the Securities Act, it did not file a registration statement under the Investment Company Act.

${ }_{107}$ The first and third reasons appear to apply with equal force to the argument that Prudential's variable annuity fund which is available to all members of the public should be exempted from the Investment Company Act. 
liability under section I2(I) of the Securities Act for their failure to register under that act and to comply with its prospectus requirements. Although this liability is probably not of practical significance in most cases, the fact that it exists is nevertheless unfortunate. Accordingly, it would seem appropriate for the Commission to incorporate its hands-off policy in interpretative and exemptive rules under the Securities Act up to the extent of its present powers; and to recommend to the Congress that section 3 (b) of the act be amended so that the Commission's exemptive rule for such plans can apply without regard to that section's present $\$ 300,000$ ceiling.

With respect to the applicability of the Investment Company Act at the level of the individual plan, section 3(c) (I3) of the Investment Company Act provides an exemption for all employee trusts which qualify under section 401 of the Internal Revenue Code. The Commission has, not without at least some difficulty, construed this exemption as applying to qualified H.R. ro trusts as well as qualified employee trusts. Such a construction of the exemption appears appropriate. To the extent that the exemption may reflect a congressional judgment that an adequate substitute for the protections of the Investment Company Act is provided by the requirements which are imposed upon such trusts under the Internal Revenue Code, the exemption should extend to H.R. Io trusts since these factors will be present to the same degree with respect to these trusts as with respect to employee pension trusts. Moreover, to the extent that the section 3 (c) (13) exemption reflects a congressional judgment that the burdens of compliance with the Investment Company Act ought not to be imposed on qualified trusts or on the employers setting them up, the exemption is if anything even more appropriate for H.R. Io trusts than for employee pension trusts since H.R. xo trusts generally will be established by smaller employers and will cover fewer persons than employee pension trusts.

The Investment Company Act does not provide an automatic exemption from its provisions for employee benefit plans that do not qualify under section 4or of the Internal Revenue Code. Section 6(b) of the act does, however, direct the Commission to grant exemptions from the provisions of the act to "employees' securities companies" if and to the extent that this is consistent with the protection of investors. Since the varieties of arrangements which can fit the act's definition of an "employees' securities company" can run the gamut from plans having all or many of the employee protections characteristic of qualified plans to plans having few or none of such protections, the flexibility which the act gives the Commission is appropriate. The Commission, however, has failed adequately to articulate general standards which should govern the granting or denial of exemptions under section 6 (b) of the act. Even though relatively few applications have so far been filed under this section, the failure of the Commission to articulate such standards is unfortunate. It would seem that one of the possible tools for assisting the decision-making process in this area is the exemption provided by section $3(\mathrm{c})(\mathrm{I} 3)$ of the act. The policy reflected by that section would suggest that the Commission should, for example, be liberal in granting complete or nearly complete exemptions to nonqualified plans 
to the extent that these have the essential employee protections contained in qualified plans. It would seem that another factor which should be considered under section 6(b) today is the extent to which the Federal Welfare and Pension Plans Disclosure Act applies to the arrangement and the nature of the protections it affords in the particular case. Other things being equal, the Commission should probably be more willing to grant exemptions to plans to which the Disclosure Act applies than to plans or arrangements to which that act is inapplicable.

When one shifts his attention from the level of the individual plan to the level of the commingled fund or other medium which may be chosen as the vehicle for investing the assets of several individual plans, a different set of considerations comes into play than is generally present at the level of the individual plan. The relationship of the employer who establishes the individual plan to the sponsor of the funding medium is essentially that of an individual with money available for investment to the seller of a security. Further, the sponsors of the funding medium (insurance companies offering variable annuities, investment-company sponsors offering investment company shares, and banks offering interests in bank commingled funds) are in the business of providing investment media. Thus, the typical situation for application of the disclosure principles of the Securities Act exists at this level.

Nevertheless, historically the Commission has not generally imposed the disclosure requirements of the Securities Act where interests in such funding media were sold exclusively to qualified employee pension plans. Although such funding media were normally sponsored by banks, this position was not based on that fact. When insurance companies began selling annuity contracts containing a segregatedfund variable feature (contracts which thus were securities) to qualified pension plans, the Commission promulgated a rule which defined the private offering exemption in a way which put the insurance companies in a very similar position with respect to disclosure requirements as that enjoyed by banks offering interests in their commingled funds to qualified pension plans. The theory on which the position with respect to both the bank and insurance company sponsored offerings rests is that the offers would be made to persons who could fend for themselvesand thus the private offering exemption should be available.

This approach reflects a proper concern by the Commission for the protection of investor interests. Distinctions should not be made on the basis of who sponsors the commingled fund. The extent to which the sponsor of the fund is regulated does not affect the investor's need for the kind of information which permits him to choose, from among various funding media, that medium which will best serve his investment objectives. And it is the underlying philosophy of the federal securities laws that decisions about the fund to be used should rest with the investor.

The Commission's pre-H.R. Io belief, that interests in commingled funds sold to qualified pension plans were being sold to persons who did not require the help of the federal securities laws in obtaining the information they needed in order 
to evaluate the comparative quality of investment media suitable for their pension plans, was probably never fully in accord with the facts surrounding all offerings or sales of such interests. Nevertheless, it probably was sufficiently in accord with the facts surrounding the preponderance of offerings and sales of such interests to constitute a defensible basis for the administrative policy which the Commission adopted. On the other hand, the circumstances which bankers themselves have indicated would surround the offerings of H.R. 1o commingled funds, plus a recognition that the employers who would be setting up H.R. Io plans would in general not be well equipped to fend for themselves, indicated to the Commission that the private offering exemption could not realistically be applied to H.R. 1o commingled funds. Although several professional or trade associations like the American Bar Association and the American Medical Association have registered the H.R. xo banktrusteed commingled funds which they are sponsoring for their members, and one bank has itself registered its H.R. Io funds, the banking industry, with the encouragement of the Comptroller of the Currency, has in general strongly resisted the Commission's position. The American Bankers Association has proposed legislation which is designed to remove bank-sponsored investment funds from the scope of the Securities Act. The Commission has quite correctly opposed this legislation. It is difficult to understand why investors in bank-sponsored investment funds should be entitled to fewer protections than investors in investment funds sponsored by others-or why banks should be afforded more favorable treatment when they decide to sponsor investment funds than are other sponsors.

As for the applicability at the level of the commingled fund of the Investment Company Act, the exemption which is provided by section $3(\mathrm{c})\left(x_{3}\right)$ of the act for qualified plans does not literally distinguish between the level of the individual plan and the level of the commingled fund. Accordingly, the commission has traditionally construed the exemption as extending at the commingled fund level to funds which are used exclusively for pooling the assets of qualified employee plans. The problem in dealing with the exemption in section 3 (c) (13) is that there is no legislative history which defines the purpose of the exemption. Two reasons for the exemption-the protections written into the Internal Revenue Code and the unwillingness to place the burdens of compliance with the Investment Company Act on employers who are not in the investment company business-suggest themselves. Of these reasons, only that regarding the protections of the Internal Revenue Code applies at the level of the commingled fund. Thus, for Investment Company Act purposes as for Securities Act purposes, the meaningful place to draw distinctions in the pension plan area would appear to be at the level of the commingled fund. However, the wording of the exemption in section $3(\mathrm{c})(\mathrm{r} 3)$ for qualified pension trusts does not differentiate between the individual plan level and the commingled fund level. Thus, when the Commission determined that 
the exemption should extend to H.R. Io plans at the individual plan level, it also extended it to H.R. Io plans at the commingled fund level.

The resulting application of the section $3(c)\left(1_{3}\right)$ exemption to the H.R. Io plan at the commingled fund level, however, makes the task of articulating the policy reasons for applying the provisions of the Investment Company Act to one kind of fund and not to another more difficult in view of the similarity between the H.R. xo commingled fund and the typical investment company. It also suggests that in certain other instances the investor protections which are accorded by the act may be eroded through changes in the character of the activities of the funds which have traditionally been exempted. It is just such erosion which, outside the pension fund area, the Commission has so far successfully resisted in the sale of variable annuities by insurance companies, and which it is currently resisting with respect to the efforts of banks to commingle managing agency accounts or to expand the activities of common trust funds without compliance with the Securities Act and the Investment Company Act. 
